
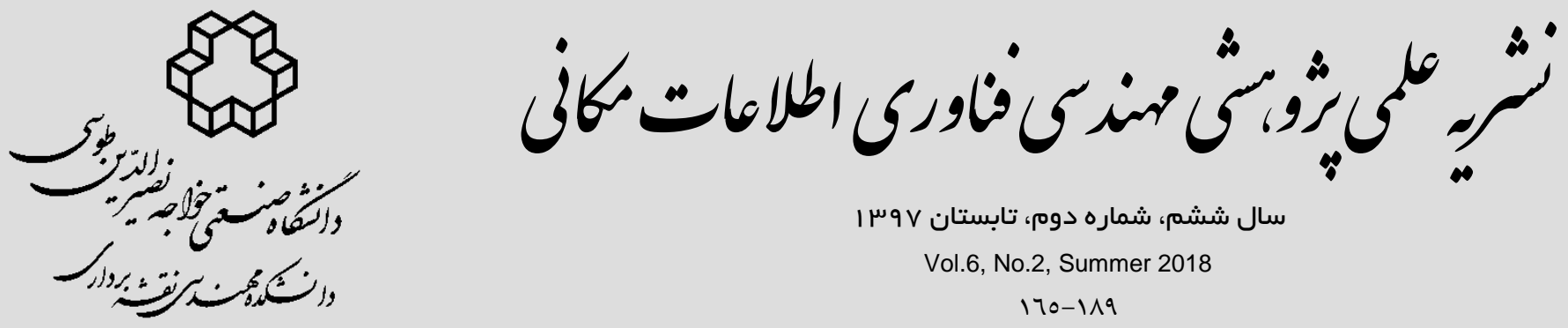

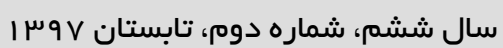

Vol.6, No.2, Summer 2018

$170-119$

اين مقاله در دومين كنفرانس ملى مهندسى فناورى اطلاعات مكانى بهعنوان مقاله بركزيده انتخاب شده /ست كه بس /ز تكميل، داورى مجدد

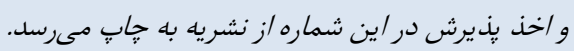

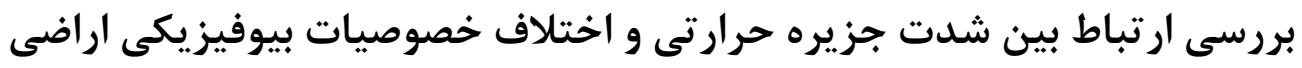
ساخته شده و غير ساختهشده (مطالعه موردى: شهرهاى شرق استان مازندران)

محمد كريمى فيروزجايى'، مجيد كياورز

1- إنشجوى دكترى كروه سنجش از دور و سيستم اطلاعات جغرافيايى دانشكاه تهران

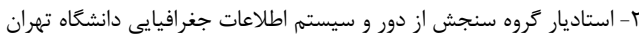

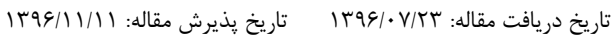

جكيده

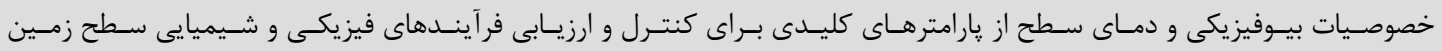

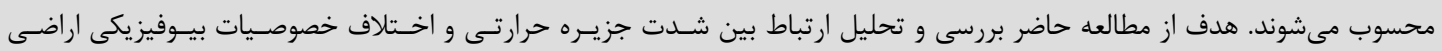

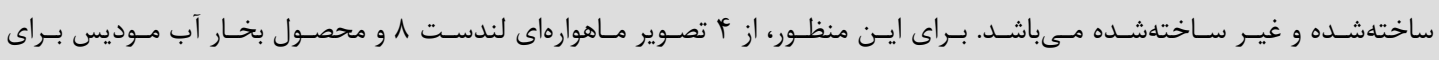

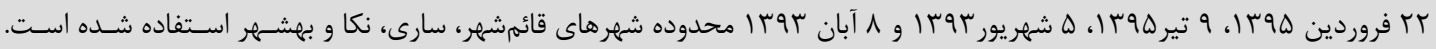

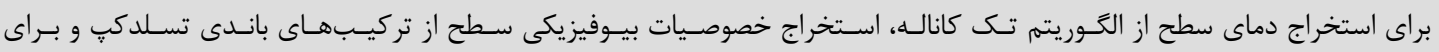

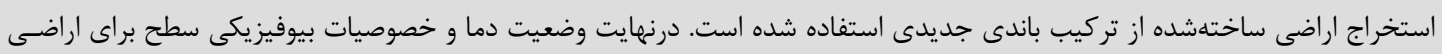

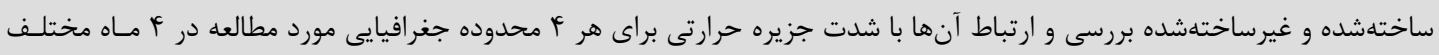

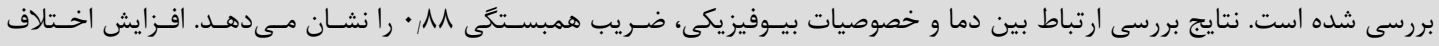

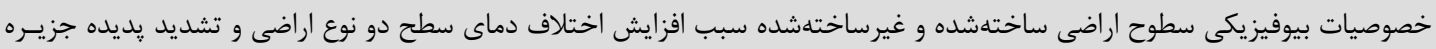

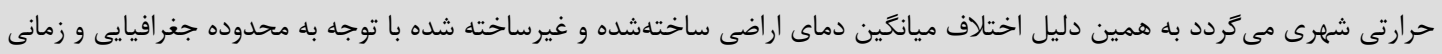

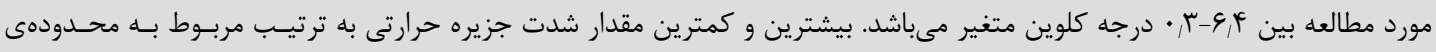

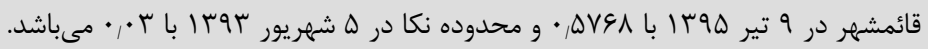

كليدوازهها: ارتباط، شدت جزيره حرارتى، خصوصيات بيوفيزيكى، اراضى ساختهشد، اراضى غير ساختهشه. 


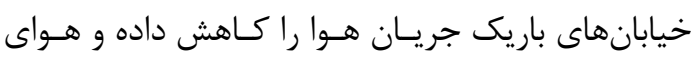

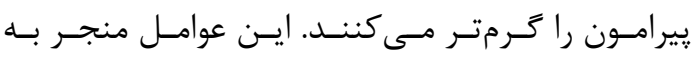

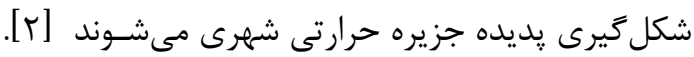

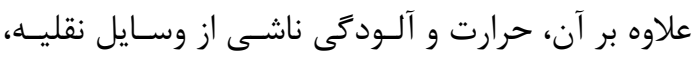

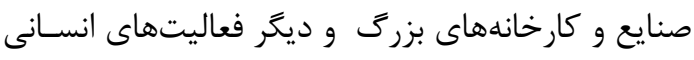
كرماى هوا را افزايش داده و اثـرات جزيــره حرارتسى ران تشديد مى كنند [هائ.

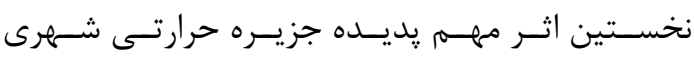

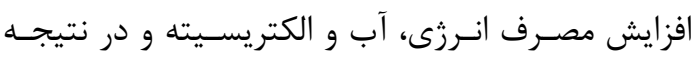
افزايش سرانه بار مالى به ويزه در مـاهـــاى كـرم سـال

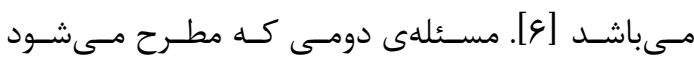

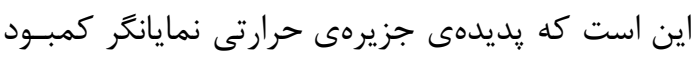

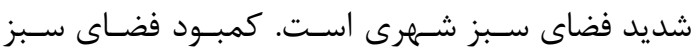

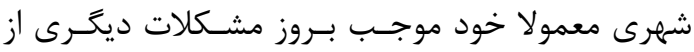

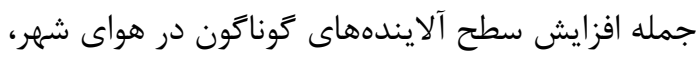
آلوده شدن، هرزآب شدن و سرانجام از دست رفـتن آب آب بارندگى ها، افزايش آلودَى صوتى و افزايش مشـكلات

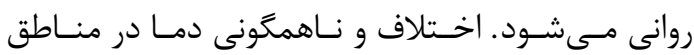
شهرى بهشدت روى كيفيت هواى محيط شـهرى تـاثير

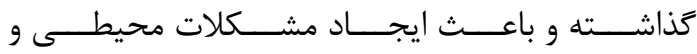
اجتماعى زيادى در محيطهاى شهرى مى شود. علاوه بر

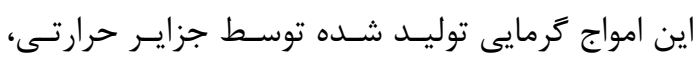
موجب تغيير الكوهاى اقليمى نظير بارش و وزش باد در ترائر

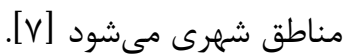
جزيره حرارتى شهرى بر اساس اختلاف دمـاى ناشسى از تفاوت خصوصيات بيوفيزيكى و نوع فعاليتهاى انسـانى إنى

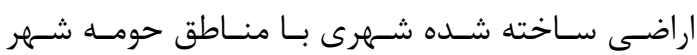

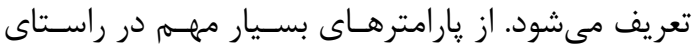

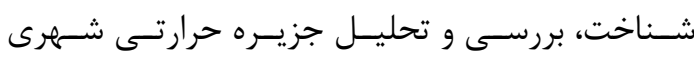

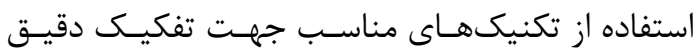
اراضى ساختهشده و غيرساختهشده از يكديكر، انتخـاب

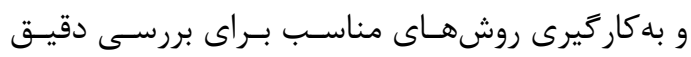

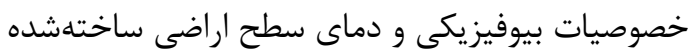
و غير ساختهشده مىباشد.

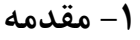

طى سالهاى كذشته رشد شهرنشينى سـبب تغييـرات عمدهاى در ساختار يوشش و كاربرىهاى اراضى سـطح

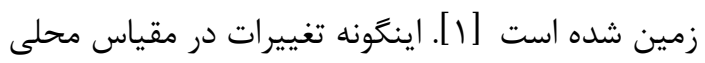
بر ميزان انرزى حرارتى تاثير كذاشته و در نتيجه باعثن

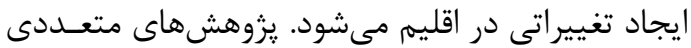

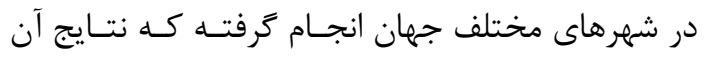
بيانكر اين است كه شهرنشـينى باعـث ايجـاد تغييـرات

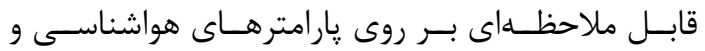

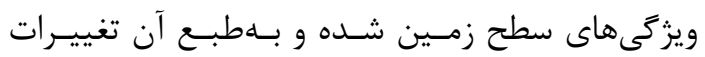

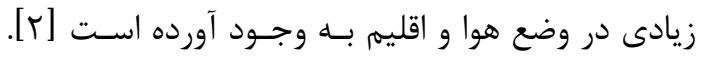

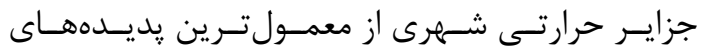

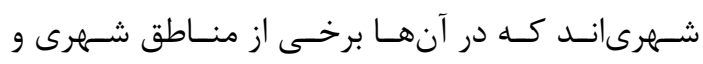

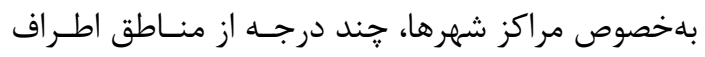

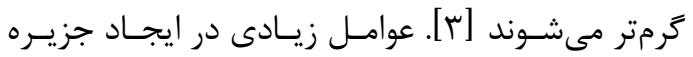
حرارتى شهرى دخيل هستند كه باطور كلى مسىتـوان

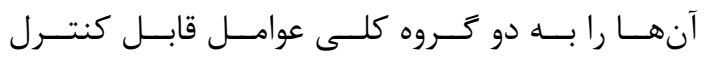

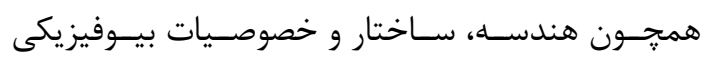

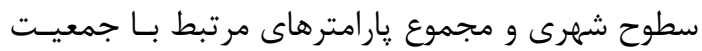

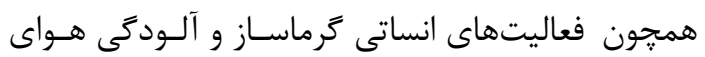

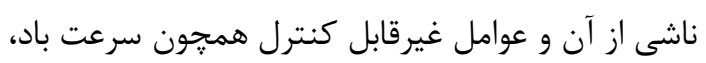

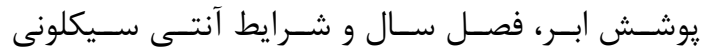

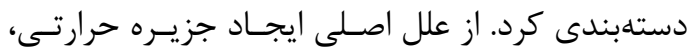

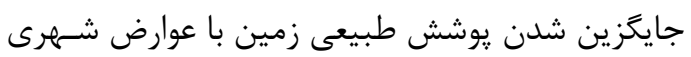

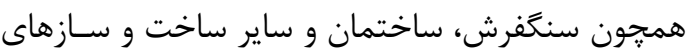

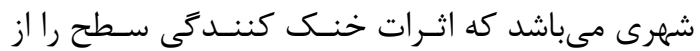

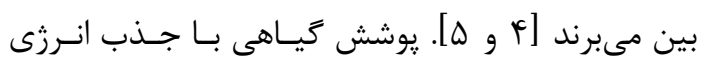

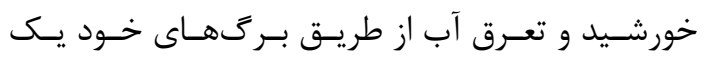
سيستم تهويه مطبوع طبيعى ايجـاد مسى كنـد. سـطوح

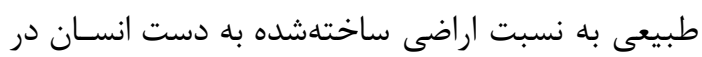

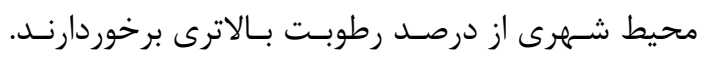

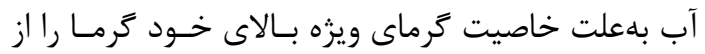

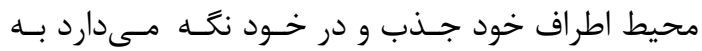

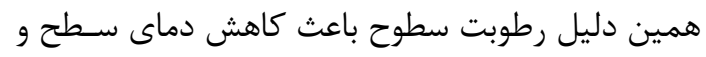
مناطق مجاور مىشود. همجنين، ساختمانهاى بلنــد و و 
متفاوت يوششهاى مختلف سطح سبب تفاوت در رفتار

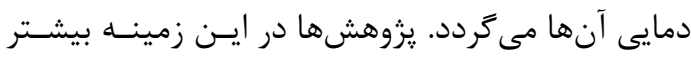

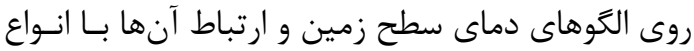
كاربرى-يوشش زمين در محيط شهرى متمركز بودهاند

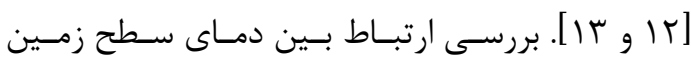
و شاخص اختلاف يوشش كَيـاهى نرمـالشـــاه

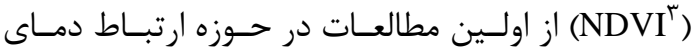

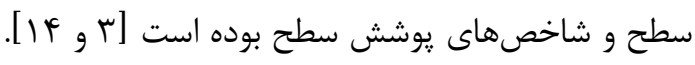

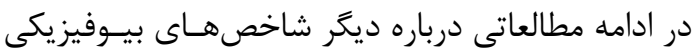
همجون كسر يوشش كياهى (FVC') و درصـد سـطوح نفوذنايذير انجام شده است كـه نتـايج نشـان از ارتبـاط

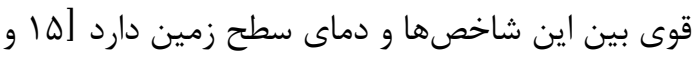

در طول دهلهاى كذشته تصـاوير مـاهوارهاى بـهـــــوان

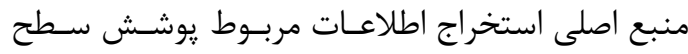

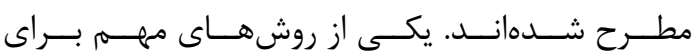

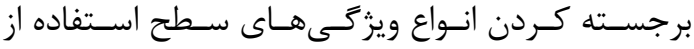

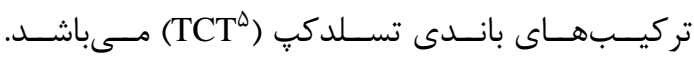

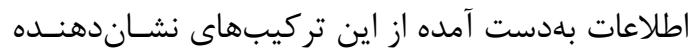

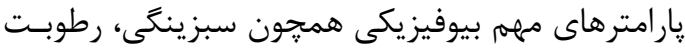

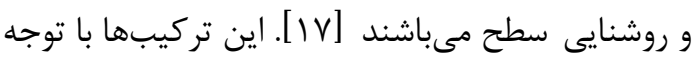

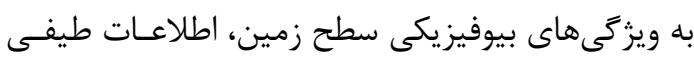

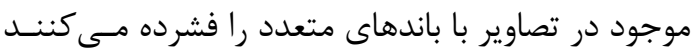

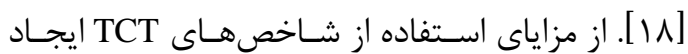
همبستخى بين باندهاى تصوير و كـاهش تعـداد بانـدها

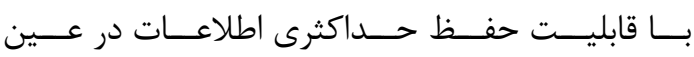

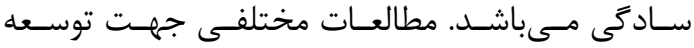
تركيبهاى باندى TCT براى تصاوير ماهوارهاى مربـوط

به سنجندهاى مختلف انجام شده است [19]

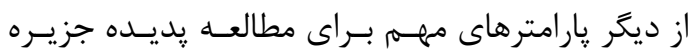

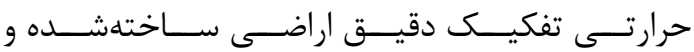

\footnotetext{
${ }^{2}$ Land Surface Temperature

${ }^{3}$ Normalized Difference Vegetation Index

${ }^{4}$ fractional vegetation cover

${ }^{5}$ Tasselled Cap Transformation
}

دماى سطح زمسين يكى از پارامترهـاى كليـدى بـراى

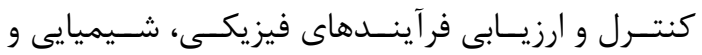
بيولوزيكى سطح زمين و يك عامل مهـم بــراى مطالعـهـ

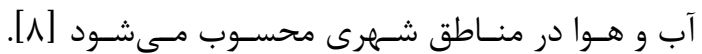

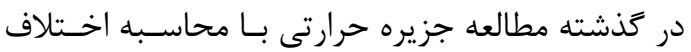

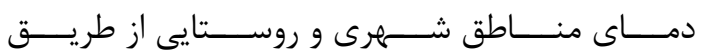

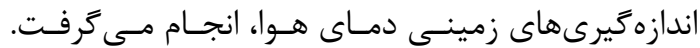

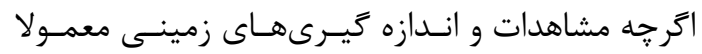

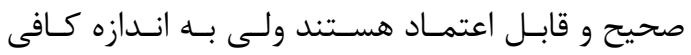
نماينده خوبى براى نشان دادن تغييرات حرارتى سـطح

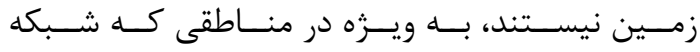

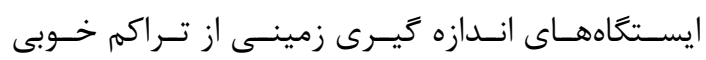

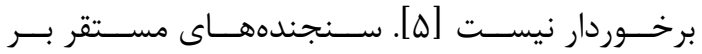
ماهوارههاى فضايى با بهـرهمنـدى از بانـدهاى حرارتى لــ

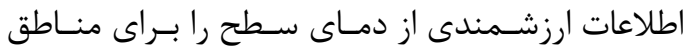

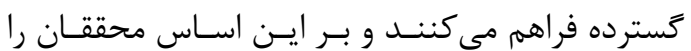
قادر مىســازند تـا تغييـرات الكوهــاى مكـانى و زمـانى

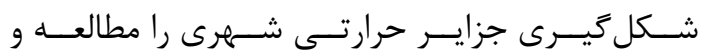

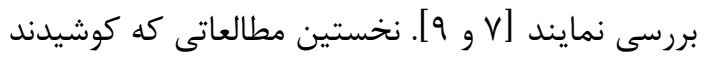

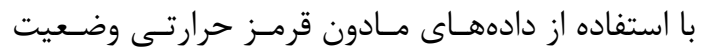

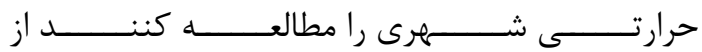

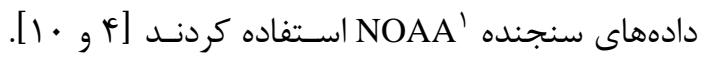
قدرت تفكيـك مكـانى بانـد حرارتـى بــراى تمـام ايـنـ

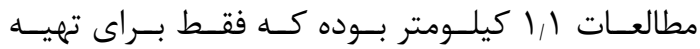
نقشه كوجى مقياس دماى شهر مناسـب مسىباشــد. بـا

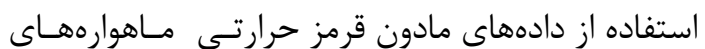

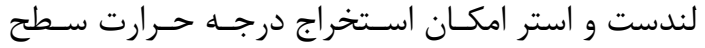

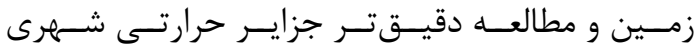
فــراهم شــده و مطالعـات متعـددى در ايــن زمينــهـ

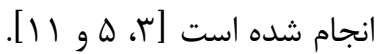
از جمله عوامل مهمم موثر بـر دمـاى سـطح و درنهايـت شدت جزيره حرارتى شهرى نوع يوشش سـطح منـاطق

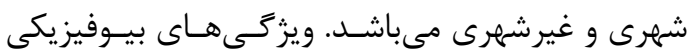

${ }^{1}$ National Oceanic and Atmospheric Administration 
اراضى ساختهشده و غيرساختهشـده بـر شـــت جزيـــه حرارتى شهرهاى مختلـف در مـاههـاى مختلـف سـال، اسـتفاده از تركيـبـهــاى بانـدى TCT بــر اســتخراج يارامترهاى بيوفيزيكى سطح و بررسى ارتبـاط آنهـا بـا

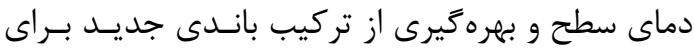

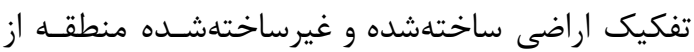
يكديخر از وجه تمايزهاى مشخص و بارز مطالعه حاضـر با مطالعات كذشته در اين حوزه مىباشد.

ץ- منطقه مورد مطالعه

منطقه مورد مطالعه شامل جهار شهر قائمشهر، سـارى،

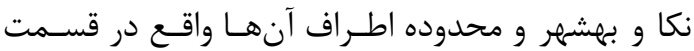

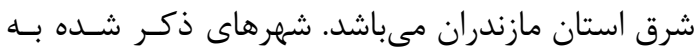

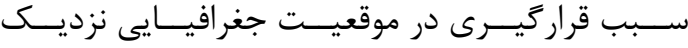

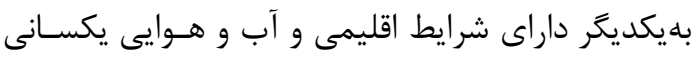
هستند. همجنين ارتفاع متوسط ايـن شـهرها از سـطح

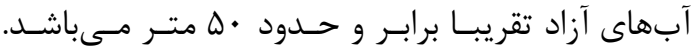
مرز محدوده اطراف هر شهر براى مطالعه به نسبت ابعاد

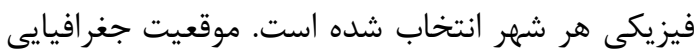
محدوده مورد مطالعه و نقاط نمونه مورد استفاده جهت بررسى ارتباط بين يارامترهاى مختلف و كنترل دقت در

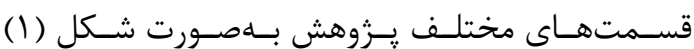
نشان داده شده است.

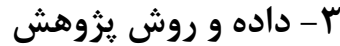

در اين بخش به معرفى دادهها، روش يـيش يــردازش و

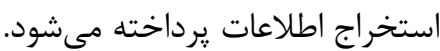

ب-1 - دادهها

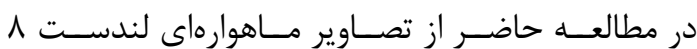
در جهمـار مــاه مختلــف ســال اسـتفاده شــده اســت. اين تصـاوير زمسـين مرجـع شــده و در سيسـتم تصـوير

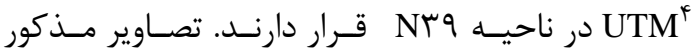
در سايت زمين شناسى امريكاه در دسترس مسىباشــد.

\footnotetext{
${ }^{4}$ Universal Transverse Mercator

${ }^{5}$ http://www.usgs.gov
}

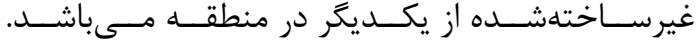

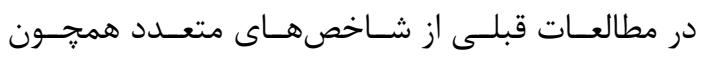

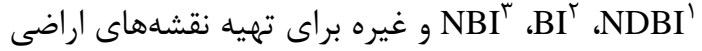

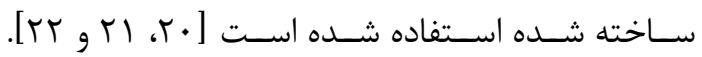
ولى در مناطق مختلف كارايى شاخصها تحت تاثير نوع

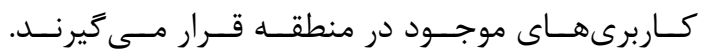

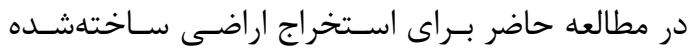
منطقه از تركيب باندى جديـدى اسـتفاده شـده اسـت.

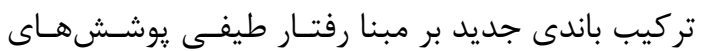

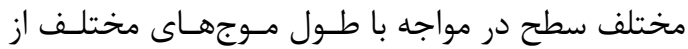

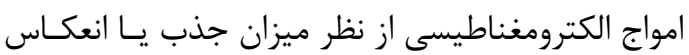

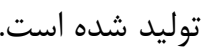

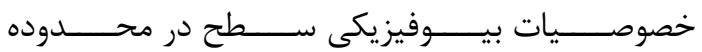
شـهرهاى شــمالى كشــور ايسران بـهـ سـبب قراركيـرى كاربرىهاى كشاورزى و فضاى سبز در محيط شـهرى و اطراف شهرها در طـول مـاههـاى مختلـف سـال داراى تغييرات زيادى مىباشد. هدف از يزوهش حاضر بررسى، تحليل و مقايسه مكانى -زمانى جگُونكى تغييرات جزيره

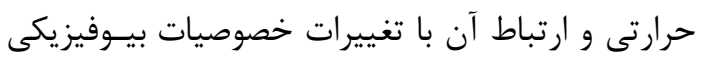

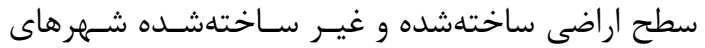
واقع در شرق استان مازندران در جهار ماه مختلف سال

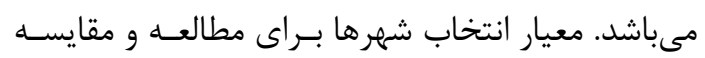
بلهصورتى بوده است كه به راحتى بهتوان اثر يارامترهاى

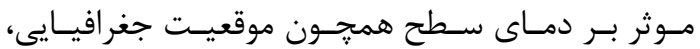

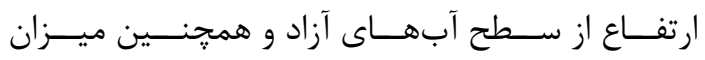

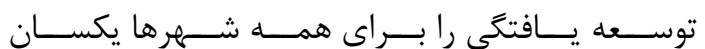
در نظــر زرفـت. مــواردى همجـــون بررسـى و مقايســهـ

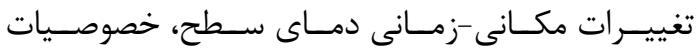

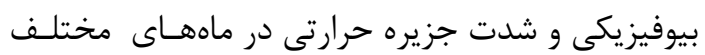

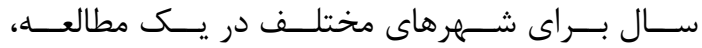
بررسى تـاثير يـارامتر اخـتلاف خصوصـيات بيـوفيزيكى

\footnotetext{
${ }^{1}$ Normalized Difference Built-up Index

${ }^{2}$ Built-up Index

${ }^{3}$ Normalized Built-up Index
} 
بررسى ارتباط بين شدت جزيره حرارتى و ....

محمد كريمى فيروزجايى، مجيد كياورز

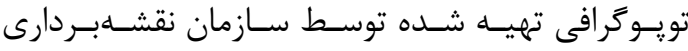

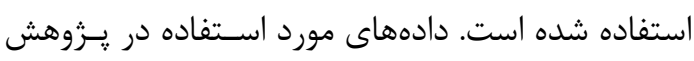
در جدول (1) نشان داده شده است.

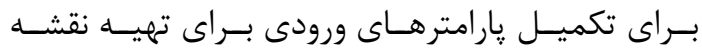

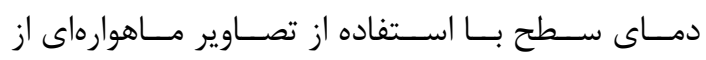

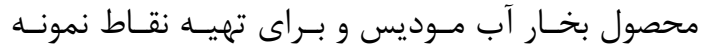

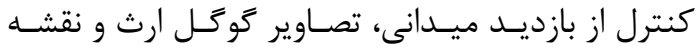

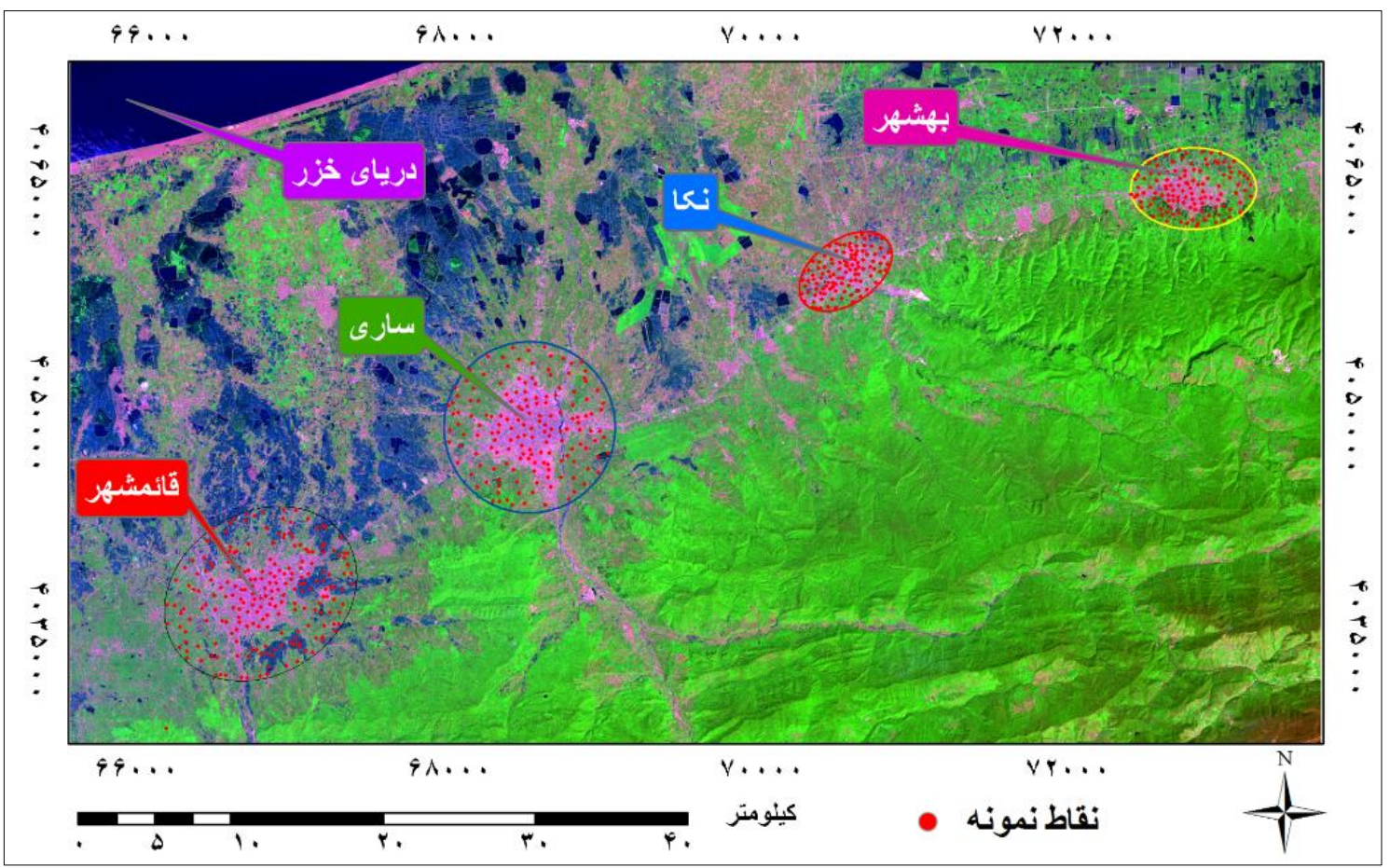

شكل ا: نقشه تركيب رنكى باندهاى V، له و سنجنده OLI ماهواره لندست ^ مربوط به منطقه مورد مطالعه.

جدول ا: دادههاى مورد استفاده يزوهش

\begin{tabular}{|c|c|c|c|c|c|}
\hline تاريخ & WRS_ROW & WRS_PATH & قدرت تفكيك & ماهواره & نوع داده \\
\hline $1 \% 9 \Delta / 1 / r r$ & ro & $19 \pi$ & 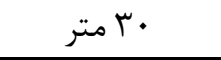 & لندست 1 & تصاوير ماهوارهاى (روز) \\
\hline $1 \% 9 \Delta / 4 / 9$ & ro & IEr & 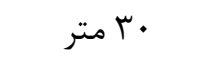 & ل لندست & تصاوير ماهوارهاى (روز) \\
\hline $\mid r q 4 / 9 / 0$ & ro & IEr & 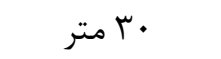 & ل لندست & تصاوير ماهوارهاى (روز) \\
\hline 1 IrqT/N/A & ro & 184 & 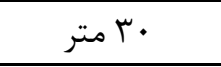 & لندست 1 & تصاوير ماهوارهاى (روز) \\
\hline 11490 & - & - & $1: r \Delta \cdots$ & --- & نقشه تويوگرافى \\
\hline- & - & - & . . ل م متر & موديس & بخار آب \\
\hline
\end{tabular}

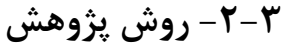

مراحل كلى انجام يزوهش به صورت شكل (r) نشان داده شده است. 


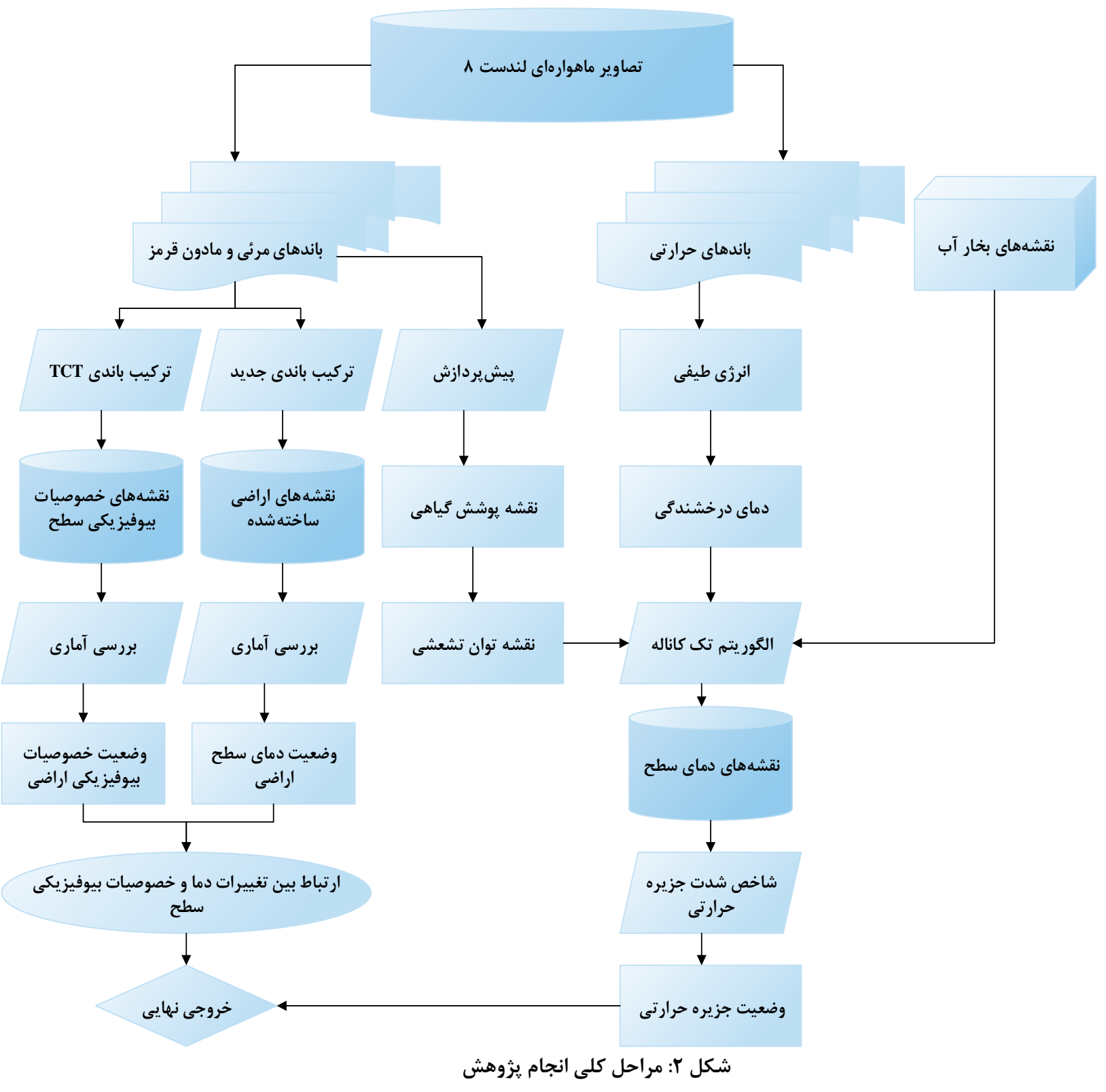

تصحيحات اتمسفرى استفاده مى كند براى ايـن منظـور

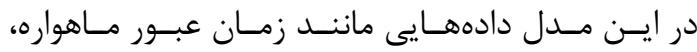

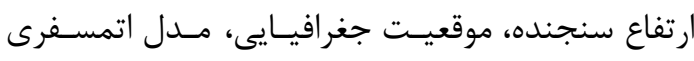

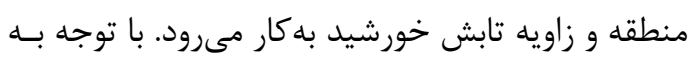

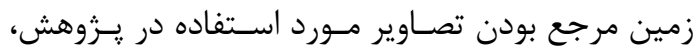

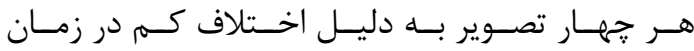

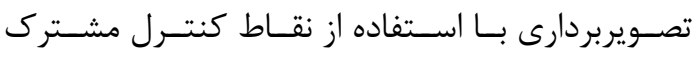

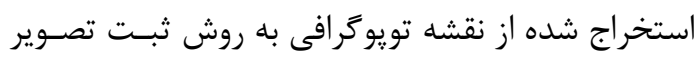
به نقشه بلهورت دقيق تصحيح هندسى شدهاند. به منظور كنترل كيفيت دادهها و برطرف كردن خطساى راديـومتريكى و هندسـى تصـاوير مــورد بررسـى اوليـهـ

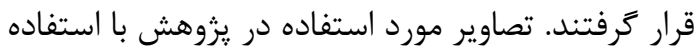

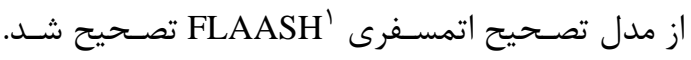

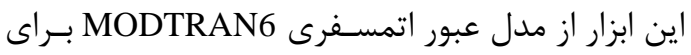

${ }^{1}$ Fast Line-of-sight Atmospheric Analysis of Hypercubes 


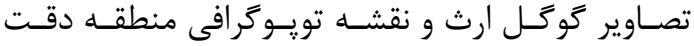
نقشههاى اراضى ساختهشده حاصل شده ارزيسابى شـد.

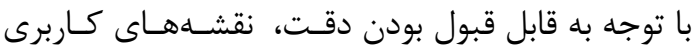

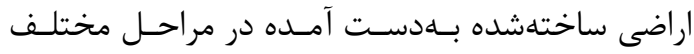
يزوهش استفاده شده است.

\section{r-r-r-r- استخراج خصوصيات بيوفيزيكى سطح}

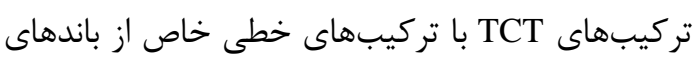
مختلف تصاوير و ماتريس ضرايب اختصاصى با توجه بــهـ ويزگ هاى فيزيكى سطح زمين، اطلاعات طيفى موجود

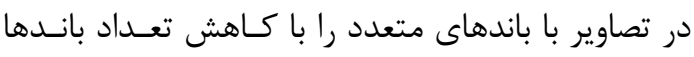

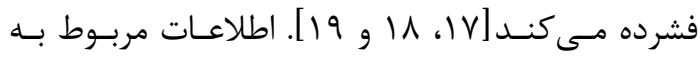
روشنايى، سبزينكى و رطوبت، سه جز اصـلى اطلاعـات

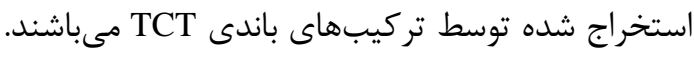

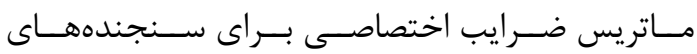

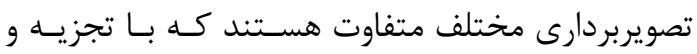

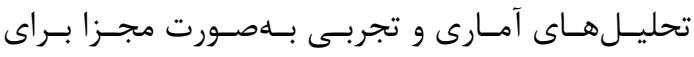
سنجندههاى مختلف محاسبه مىشوند. ضرايب مربـوط إس

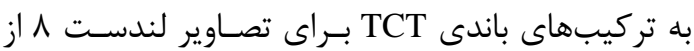

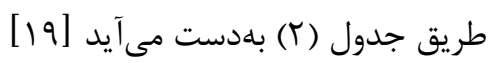

r-Y-Y-Y - استخراج اراضى ساختهشده براى استخراج اراضى ساختهشده تركيب باندى جديدى

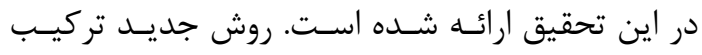

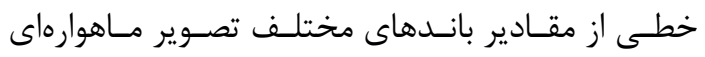

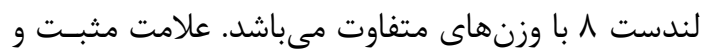
منفى و مقادير هر يك از وزنها از طريق بررسى دقيـق

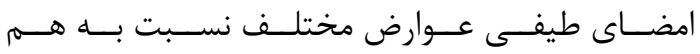

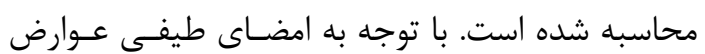

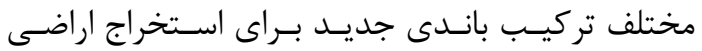
ساختهشده، بلصورت رابطه ( (1) نشان داده شده است.

رابطه (1) Built up $=0 / 8239$ Band $_{2}-0 / 0849$ Band $_{3}-$ $0 / 4396$ Band $_{4}+0 / 058$ Band $_{5}-0 /$ 2013 Band $_{6}+0 / 2773$ Band $_{7}$ در رابطــهـ (1)، Band بand ${ }_{4}$

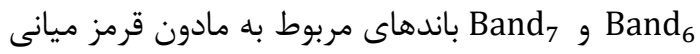

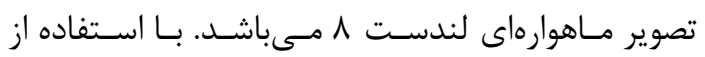

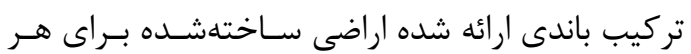

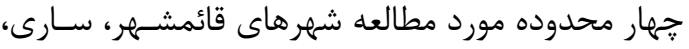

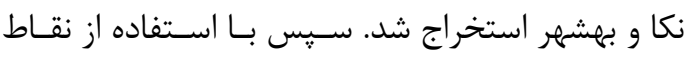

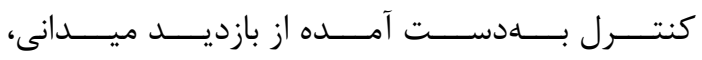

جدول ץ: ضرايب مربوط به تركيبهاى TCT براى تصاوير لندست 1

\begin{tabular}{|c|c|c|c|c|c|c|c|}
\hline باند & باند ا & باند r & باند r & باند F & باند هـ & باند 9 & ل \\
\hline روشنايى & $\cdot 1 \cdots$ & $\cdot r \cdot r q$ & $\cdot / r \vee \wedge \varepsilon$ & . IFVMr & .10099 & $\cdot 10 \cdot 1$ &.$/ 1 \wedge V T$ \\
\hline سبزينكى & $\cdot 1 \cdot \cdots$ & $-\cdot|r q 4|$ &.$- / T F T$ &.$- / D F T F$ & - IVTVG &.$|\cdot V| r$ & $-\cdot / 19 \cdot 1$ \\
\hline رطوبت رطت & $\cdot 1 \cdots$ &.$/ 1110$ &.$/ 19 V r$ & - TrAK & $\cdot / K F \cdot V$ & $-\cdot / V I I V$ & $-\cdot / \uparrow \Delta \Delta Q q$ \\
\hline
\end{tabular}

كياهى NDVI و كسر يوشش كياهى بلدست مسى آيـد.

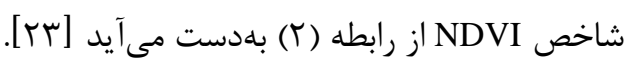
رDVI= $\frac{\rho_{\text {nir }}-\rho_{\text {red }}}{\rho_{\text {nir }}+\rho_{\text {red }}} \quad$ (T) 管 $\rho_{\text {nir }}$

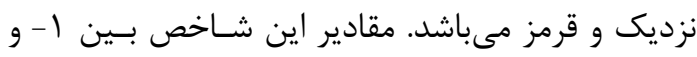
1+مىباشد. كسر يوشش كياهى با استفاده از رابطه (r) محاسبه مىشود [rr]

\section{r-Y-r}

بــراى محاسـبه دمــاى سـطحح زمسين ابتــدا بايسـد تـوان

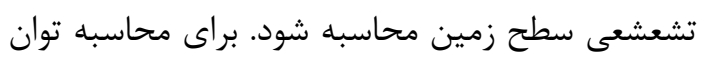

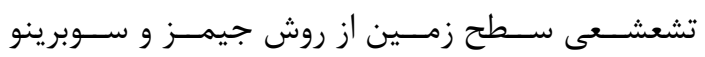

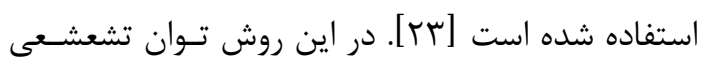

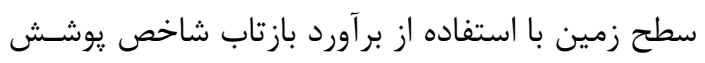


با بهدست آوردن كسر يوشـش كيـاهى، تـوان تشعشى

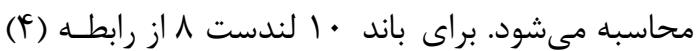
براى محاسبه توان تشعشى استفاده مىشود.
$\mathrm{FVC}=\left(\frac{(\text { NDVI-NDVIS }}{\left(\mathrm{NDVI}_{\mathrm{V}}-\mathrm{NDVI}_{\mathrm{S}}\right)}\right)^{2}$

رابطه (广) در اين رابطه، NDVI مربوط به يوشش گياهى متراكم

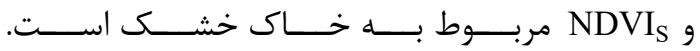

\section{IF FVC $=0 \quad$ Then $\quad$ LSE $=0.979-0.046 \rho_{\text {red }}$}

IF $0<\mathrm{FVC} \leq 1 \quad$ Then $\quad$ LSE $=0.971(1-\mathrm{FVC})+0.987 \mathrm{FVC} \quad$ (f)

IF $\mathrm{NDVI}<0 \quad$ Then $\quad$ LSE $=0.991$

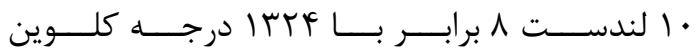
در نظر كرفته مىشـود. W ميـزان بخـار آب موجـود در

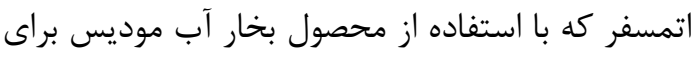
تاريخ موردنظر بلهدست مى آيد.

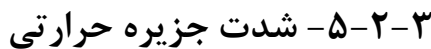

جهـت بررسى تغييـرات مكـانى -زمـانى دمـاى سـطح، نقشههاى دماى سطح منطقه با روشهاى آمارى تجزيه و تحليل شدند. در اين يزوهش با استفاده از دو يـارامتر

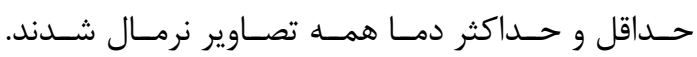

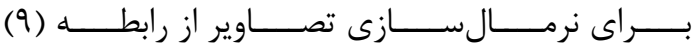

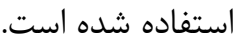

$\mathrm{NLST}_{i}=\frac{\mathrm{LST}_{i}-\mathrm{LST}_{\text {min }}}{\mathrm{LST}_{\text {max }}-\mathrm{LST}_{\text {min }}}$

(9)

رابطه (با)، NLST مقـدار دمـاى سـطح نرمـال شـــ

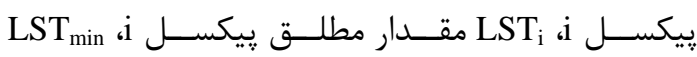

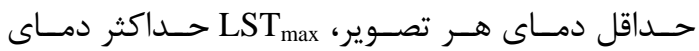
هر تصوير مىباشد.سيس تصاوير نرمال شده مطـابق بـا جدول (r) با استفاده از مقادير ميانكَين و انحراف معيار

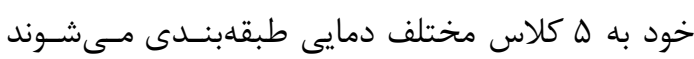

.[ro]
كه در رابطه فــوق، PVC كسر يوشش كياهى مىباشد. براى محاسبه دماى سطح

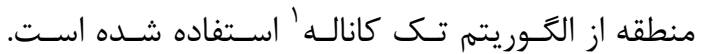

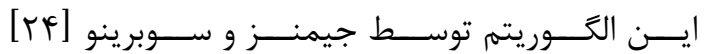

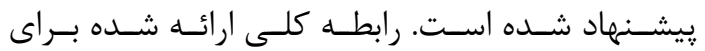

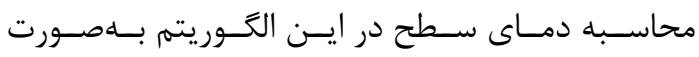
رابطه (ه) مىباشد.

$$
\text { رST }=\gamma\left[\frac{1}{\varepsilon}\left(\psi_{1} \mathrm{~L}_{\mathrm{sen}}+\psi_{2}\right)+\psi_{3}\right]+\delta \quad \text { (ब) }
$$

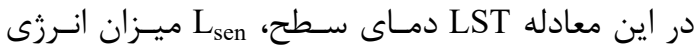
ثبت شده در سنجنده براى باند حرارتى، ع ميزان تـوان تشعشى مربوط به طول موج باند حرارتى مورد استفاده،

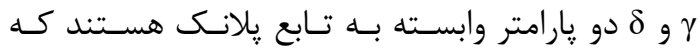

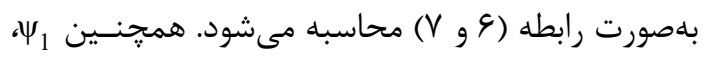

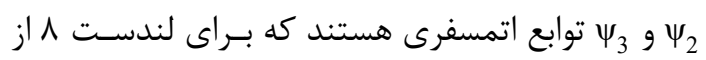

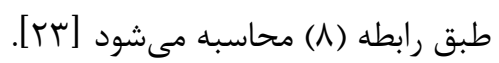

$$
\begin{array}{ll}
\gamma=\frac{T_{\text {sen }}^{2}}{b_{\lambda} L_{\text {sen }}} & \text { رابطه } \\
\delta=-\gamma \times L_{\text {sen }}+T_{\text {sen }} & \text { (V) رابطه (^) }
\end{array}
$$

$\left\{\begin{array}{l}\psi_{1}=0.04019 \mathrm{~W}^{2}+0.02916 \mathrm{~W}+1.01523 \\ \psi_{2}=-0.38333 \mathrm{~W}^{2}-1.50294 \mathrm{~W}-0.20324 \\ \psi_{3}=0.00918 \mathrm{~W}^{2}+1.36072 \mathrm{~W}-0.27514\end{array}\right.$

كه در اين رابطهها، Ton دماى درخشند در سنجنده، Lيزان ميزان انرزى ثبت شــده در ســنجنده

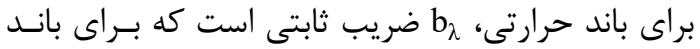

${ }^{1}$ single-channel 
جدول r: نحوه طبقدبندى دماى سطحى به ه طبقه دمايى

\begin{tabular}{|c|c|}
\hline دامنه مربوط به هر طبقه & طبقه \\
\hline $\mathrm{LST} \leq \mathrm{LST}_{\text {mean }}-1.5 \mathrm{std}$ & 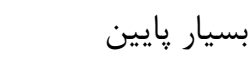 \\
\hline $\mathrm{LST}_{\text {mean }}-1.5 \mathrm{std}<\mathrm{LST} \leq \mathrm{LST}_{\text {mean }}-\mathrm{std}$ & 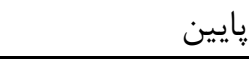 \\
\hline $\mathrm{LST}_{\text {mean }}-\mathrm{std}<\mathrm{LST} \leq \mathrm{LST}_{\text {mean }}+$ std & 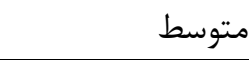 \\
\hline $\mathrm{LST}_{\text {mean }}+\mathrm{std}<\mathrm{LST} \leq \mathrm{LST}_{\text {mean }}+1.5 \mathrm{std}$ & بالا \\
\hline $\mathrm{LST}_{>}>\mathrm{LST}_{\text {mean }}+1.5 \mathrm{std}$ & 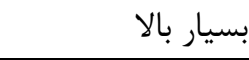 \\
\hline
\end{tabular}

محدودههاى مختلف در ماههاى متفاوت مـورد مطالعـهـ

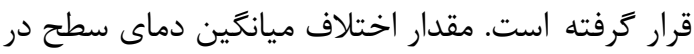
دو طبقه اراضى ساختهشده و غير ساختهشده بررسى و

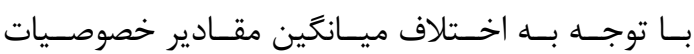
بيوفيزيكى سطح تحليل شـده اسـت. در نهايـت شـدت

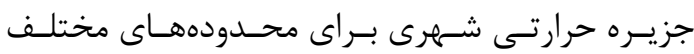
محاسبه و با يكديكر مقايسه شده است.

\section{P}

در اين بخش بـهـ ارائـهـ نتـايج بـهـدست آمـده و بحــث

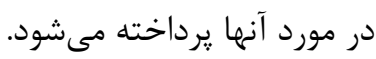

\section{ץ-1 - استخر اج اراضى ساخته شده}

نتـايج ارزيـابى دقـت تصـحيح هندسـى تصـاوير مـورد

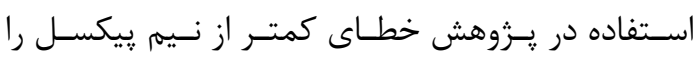

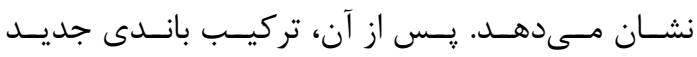

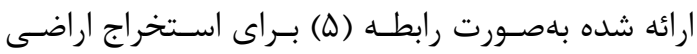

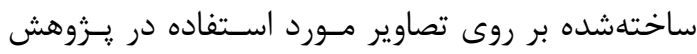

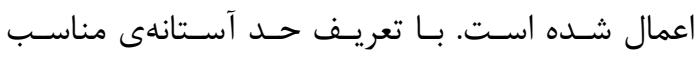

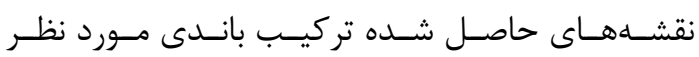

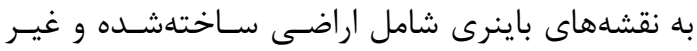

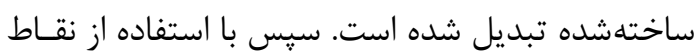

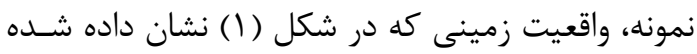
دقت تركيب باندى براى استخراج اراضى سـاخته شـده محاسبه و بلهورت جدول (F) نشان داده شده است.
در جدول (ب)، LST

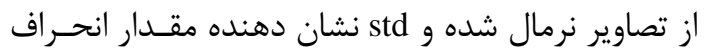

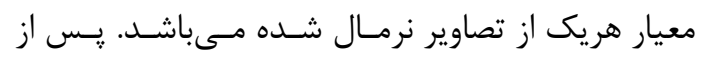

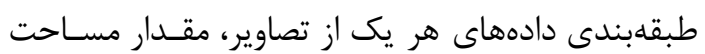
هـر يـك از طبقـات دمـايى محاسـبه و رونـد تغييـرات

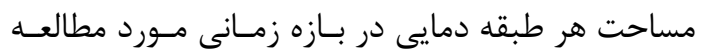
بررسى شده است. جهت بررسى تغييرات شدت جزيره حرارتى منطقه بين

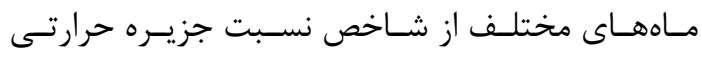

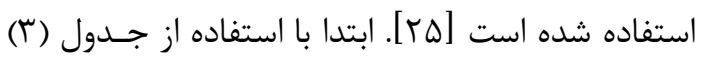

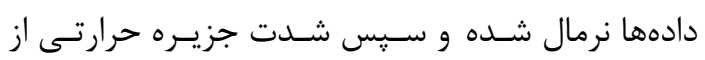
طريق رابطه ( • () محاسبه مىشود.

$\mathrm{URI}=\frac{1}{100 \mathrm{~m}} \sum_{\mathrm{i}=1}^{\mathrm{n}} \mathrm{W}_{\mathrm{i}} \mathrm{P}_{\mathrm{i}}$

رابطه (·)

در رابطه ( • ()، URI شاخص شدت جزيره حرارتىى، تعداد طبقات دماى نرمال شده، n تعداد طبقات دمـايى

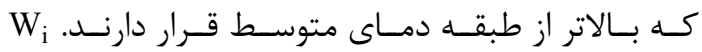

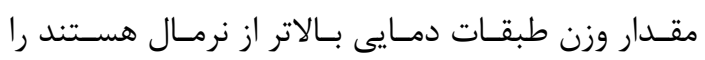
نشان مىدهد كه با توجه به شماره طبقه وزنها لحساظ مىشود. Pقدار مساحت طبقات دمايى بالاتر از نرمال در فضاى اراضى ساختهشده شـهرى بـهـ كـل مســاحت اراضى ساختهشده شهرى را نشان مى دهدي.

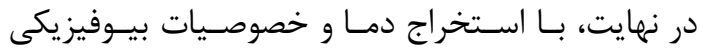
سطح، ارتباط بين هر يك از پارامترها بررسى و تحليـل

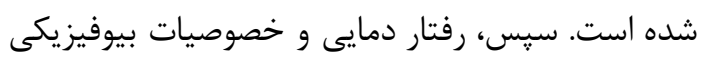


جدول f: دقت تركيب باندى ارائه شده براى استخراج اراضى ساختهشده

\begin{tabular}{|c|c|c|c|c|}
\hline شهر & قائمشهر & 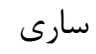 & نكا & بهشهر \\
\hline تعداد نقاط نمونه اراضى ساختهشده & gf & $9 \Lambda$ & et & ¡人 \\
\hline تعداد نقاط نمونه اراضى غير ساختهشده & 111 & $1 \cdot 1$ & $\vee v$ & $9 \wedge$ \\
\hline تعداد نقاط نمونه قرار گرفتهشده در طبقه ساختهشده & $\Delta \Lambda$ & द. & rq & reta \\
\hline دقت كلى (درصد) & 9 . & $\Lambda$ & 94 & 19 \\
\hline
\end{tabular}

نقشههاى اراضى ساختهشده براى جهار محدوده مورد مطالعه تهيه و بهصورت شكل (r) نشان داده شده است.
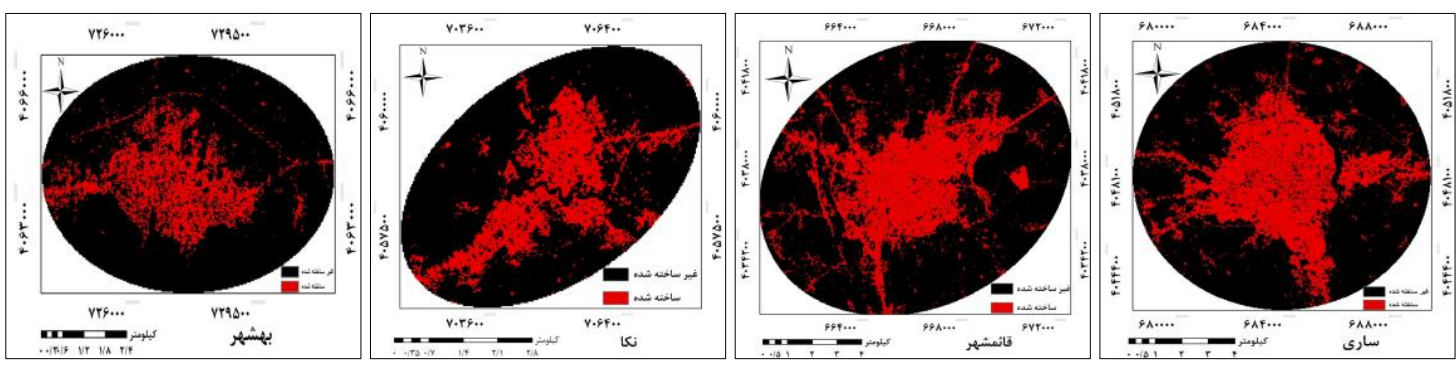

شكل ץّ: نتايج حاصل از اعمال تركيب باندى جديد بر روى تصوير ماهوارهاى لندست ^ براى تهيه نقشه اراضى ساخته شده

مساحت اراضى ساختهشده و غير ساختهشده بـه تفكيـك محـدوده مـورد مطالعـه اسـتخراج و بـهـــورت جـدول (ه) بيان شده است.

جدول ه: مساحت اراضى ساختهشده و غير ساختهشده محدودههاى مورد مطالعه (هكتار)

\begin{tabular}{|c|c|c|c|c|}
\hline شهر & قائمشهر & 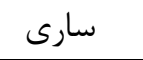 & نكا & بهشهر \\
\hline مساحت اراضى غير ساختهشده & $\Lambda / r q / \Lambda \Lambda$ & $9909 / 91$ & IVIV/VF & $r \wedge r \Delta / 9 \Lambda$ \\
\hline مساحت اراضى ساختهشده & $r \cdot r l / V F$ & rq४q & $\Delta r q / q F$ & GTI/VT \\
\hline
\end{tabular}

r-f

نتايج محاسبه دمـاى سـطح منــاطق مـورد مطالعـه در

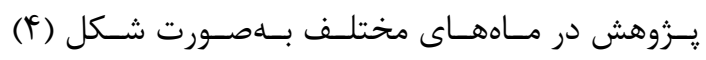
نشان داده شده است. 


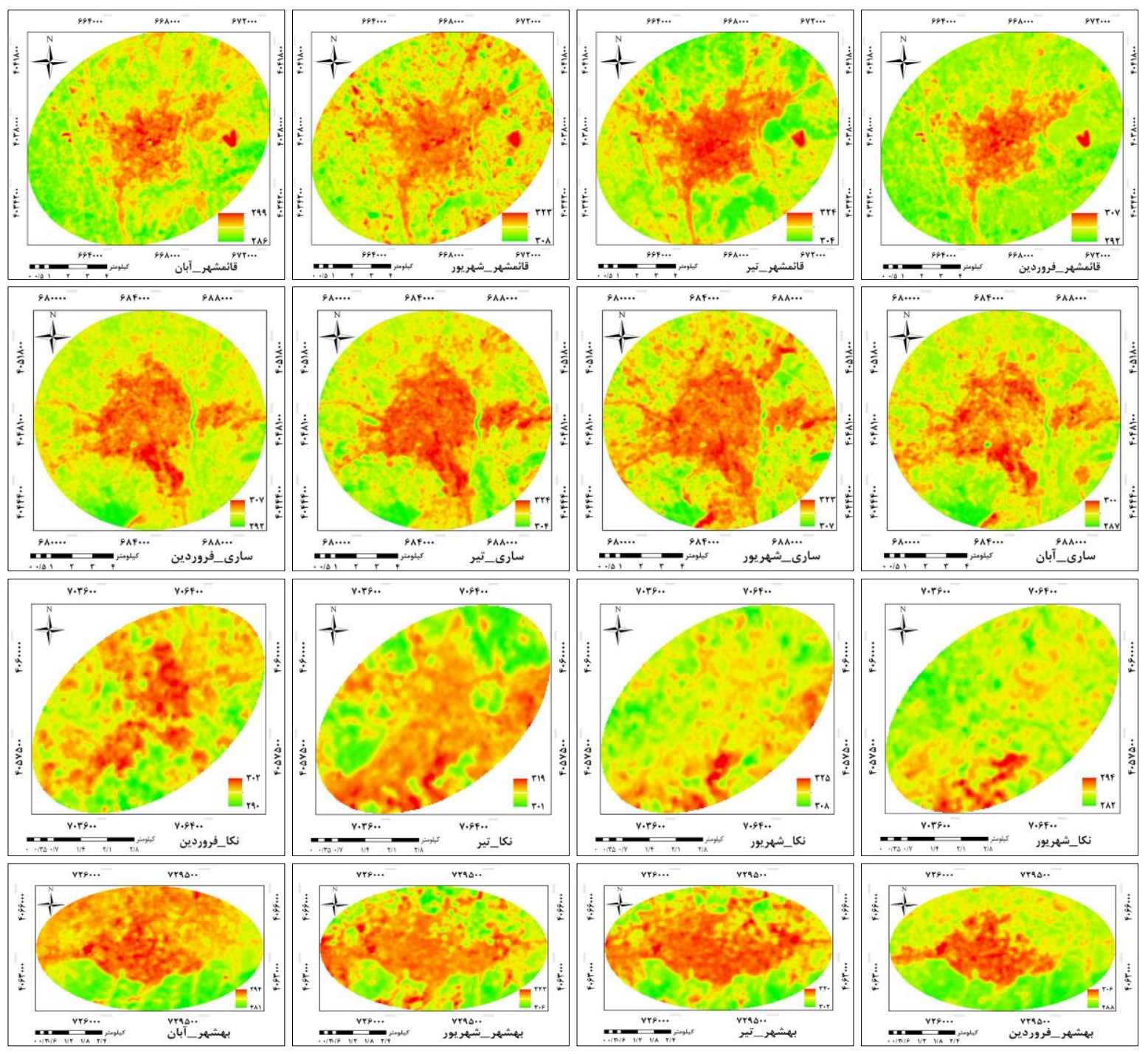

شكل f: نقشه هاى دماى سطح محدودههاى مورد مطالعه در يزوهش در ماههاى مختلف (درجه كلوين)

ميـانغين دمـاى سـطحح اراضـى سـاختهشـــه و غيـر

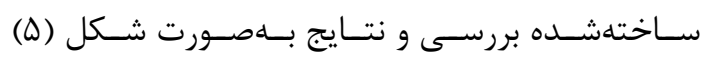
نشان داده شده است. 


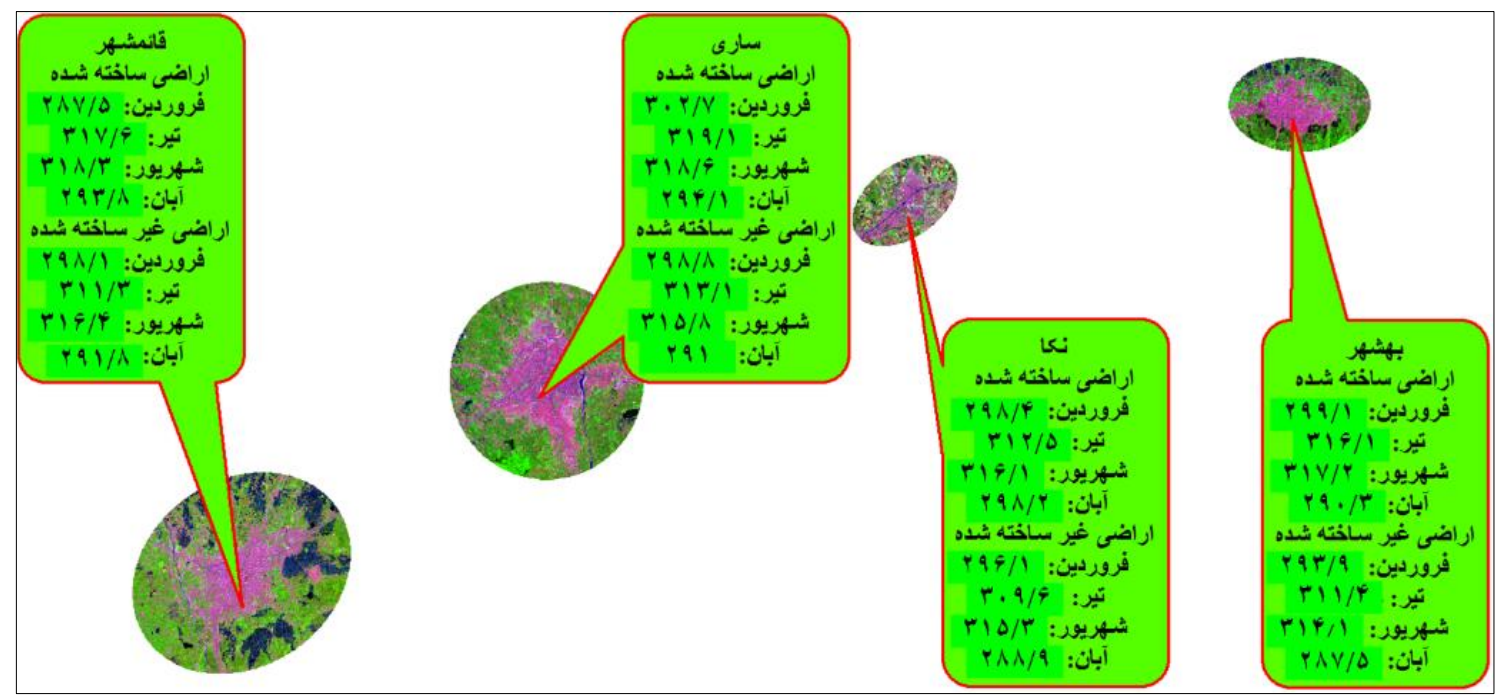

شكل ه: ميانكين دماى سطح اراضى ساختهشده و غير ساختهشده (درجه كلوين)

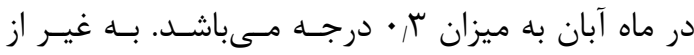
محدوده بهشهر كه در آن بيشترين اختلاف دماى سطح بين كاربرى اراضى ساختهشده و غير ساختهشده مربوط

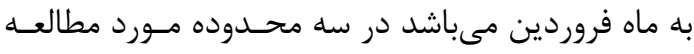

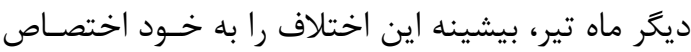

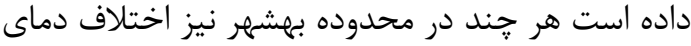

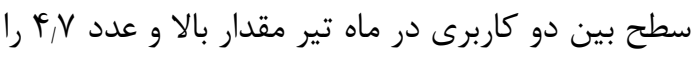

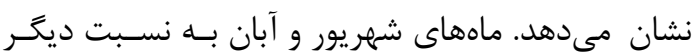

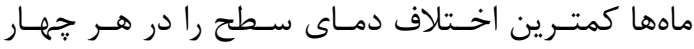
محدوده مورد مطالعه دارند. در بين محدودههاى مـورد بررسى سارى و نكا به ترتيب داراى بيشتر ين و كمترين

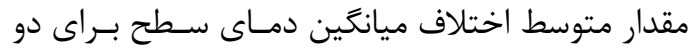

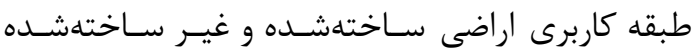

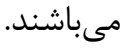

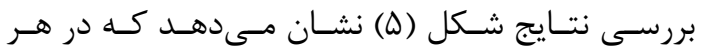
دو كاربرى ساختهشده و غير ساختهشده در ماههاى تير و شهريور داراى بيشترين و در ماه آبان داراى كمتـرين

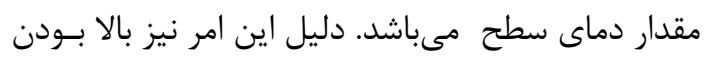

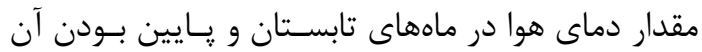
در فصل קاييز مىباشـد. در بـين קههار محـدوده مـورد مطالعه، محدوده سارى و قائمشـهر داراى دمـاى سـطح بالاترى نسبت به محدودههاى نكا و بهشهر مسى باشــند.

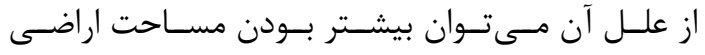

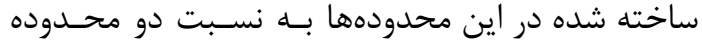
نكاو بهشهر اشاره كرد. اراضى ساخته شده در همه ماهها و محـدودههــاى مـورد بررسى داراى دمـاى سـطح

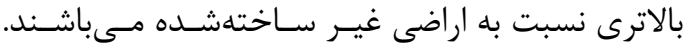

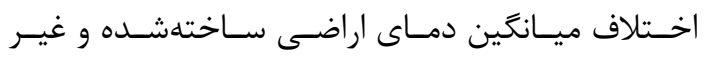
ساختهشده براى محدودههاى خاص در ماههاى مختلف

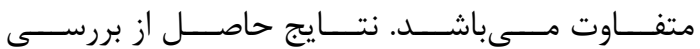

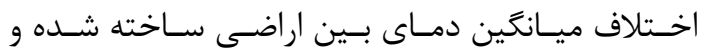
غير ساخته شده براى محدودههاى خـاص در مـاههـاى إلى مختلف بلصورت شكل (9) نشان داده شده است. مطابق شكل (9)، بيشترين و كمترين اختلاف ميـانگين دماى سطح دو نوع كاربرى به ترتيب مربوط به محدوده

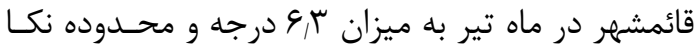




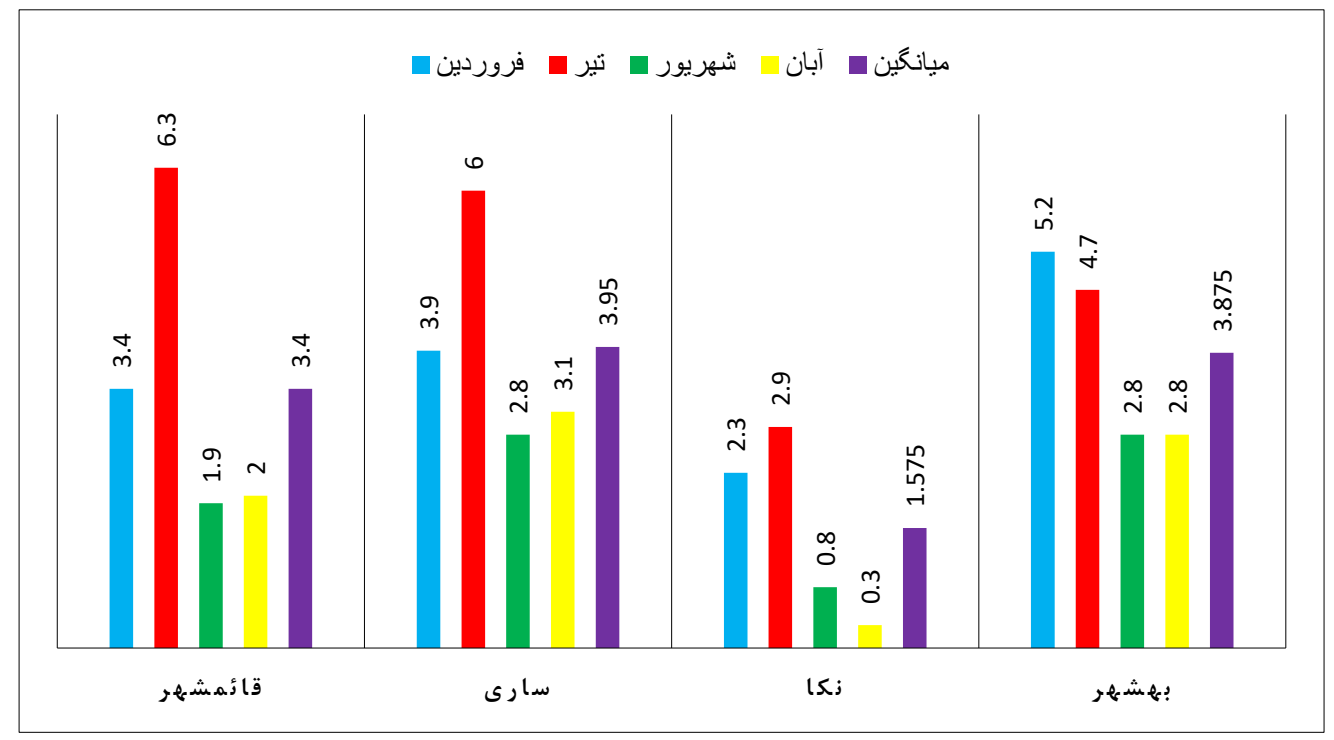

شكل 9: اختلاف ميانكين دماى سطح اراضى ساختهشده و غير ساختهشده براى محدودههاى خاص در ماههاى مختلف

و رطوبت بررسى شـده اسـت. نقشـهـــاى خصوصـيات

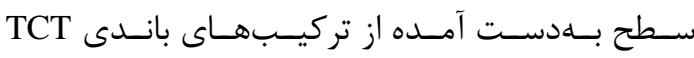

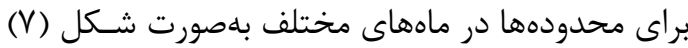

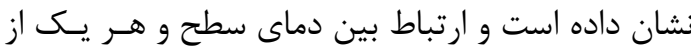

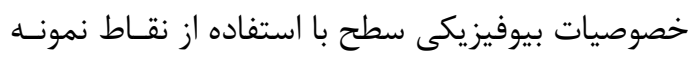


نشان داده شده است

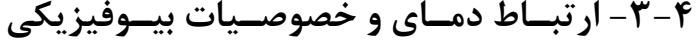
سطح جهـت بررسـى دقيـقتـــر علـت اخــتلاف ميـانكَين

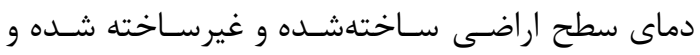

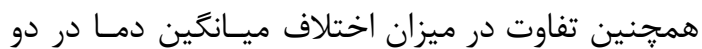

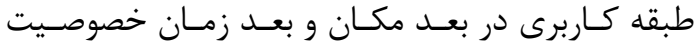
بيوفيزيكى تاثيركذار سطح از جمله روشنايى، سبزينكى لعى 


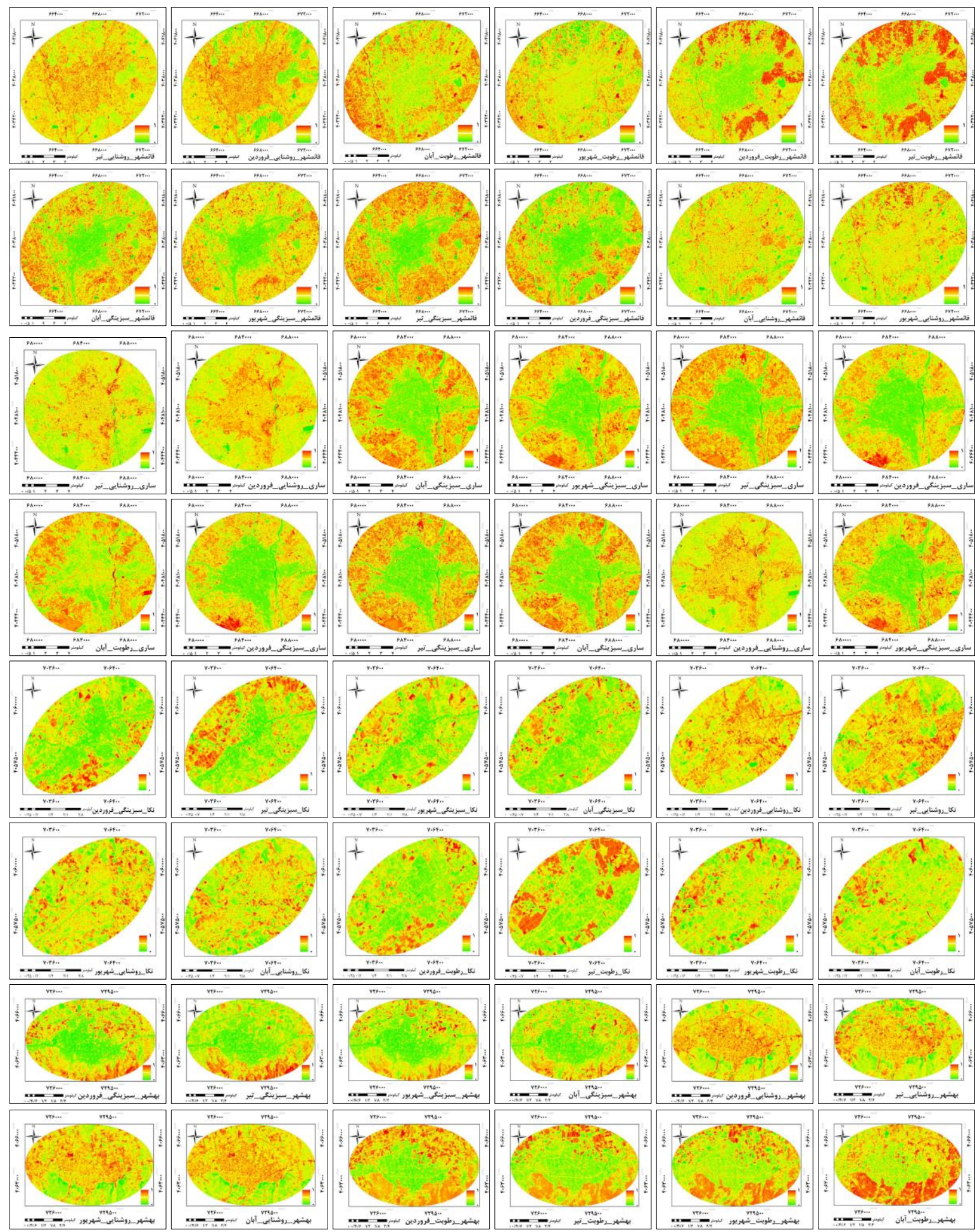

شكل V: نقشههاى خصوصيات سطح بهدست آمده از تركيبهاى باندى TCT براى محدودههاى جغرافيايى متفاوت در ماههاى مختلف 
خطى معكـوس وجــود دارد. معنـادار بــودن ضـرايب در

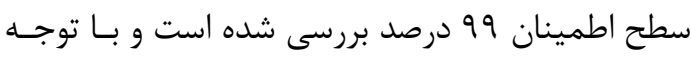
به مقادير حاصل شده براى آمـاره t و F معنـادار بـودن روابط تاييد شده است.
نتايج بررسى ارتبـاط بـين دمـاى سـطح و خصوصـيات

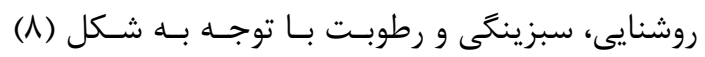

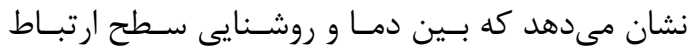
خطى مستقيمى و دما با سبزينگ四 رطوبت سطح ارتباط

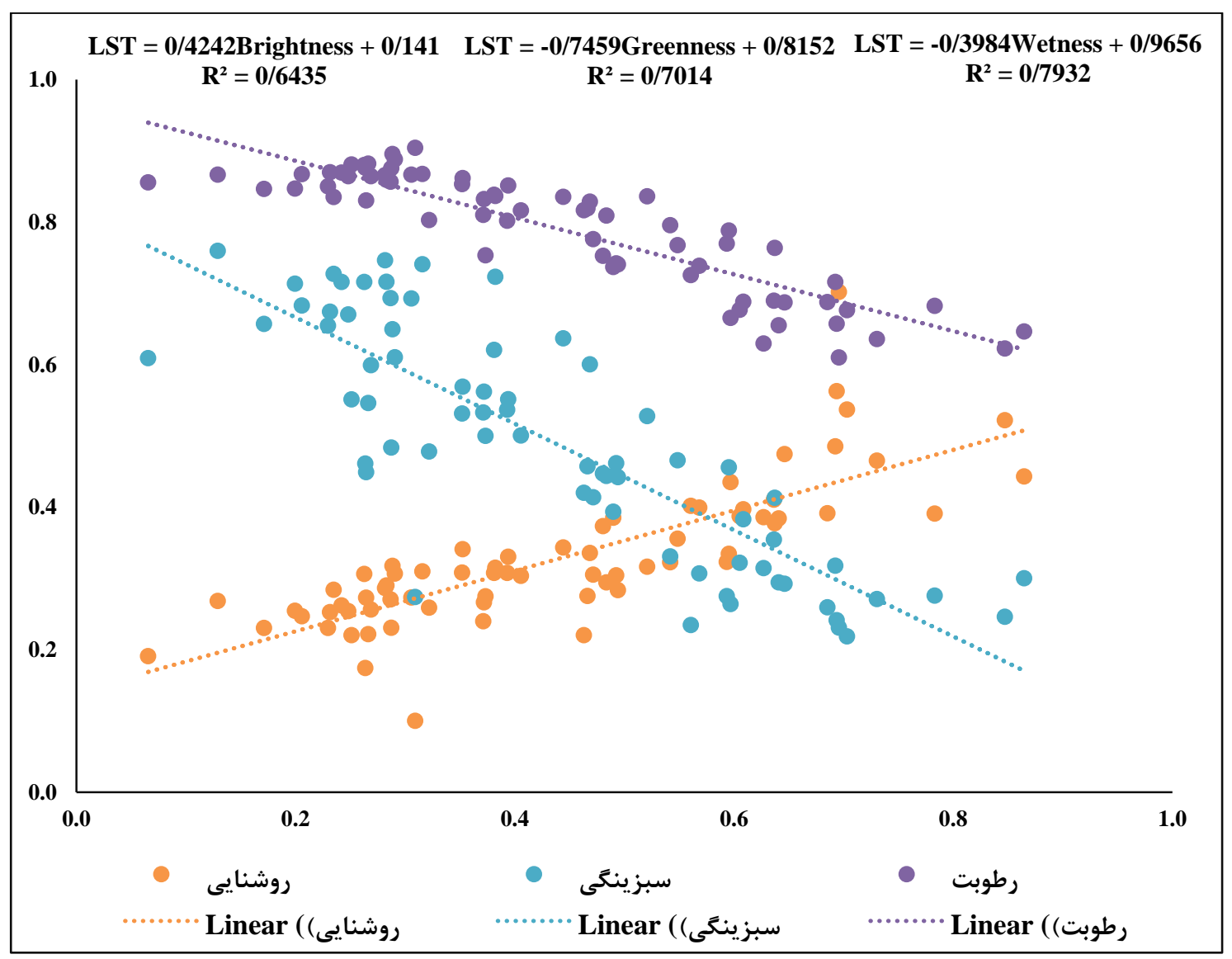

شكل ^: ارتباط بين دما و خصوصيات بيوفيزيكى سطح. محور عمودى مربوط به دما و محور افقى نشاندهنده خصوصيات بيوفيزيكى سطح.

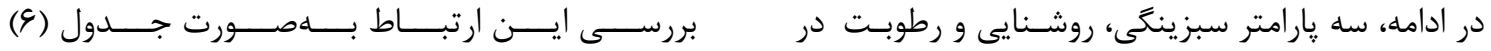

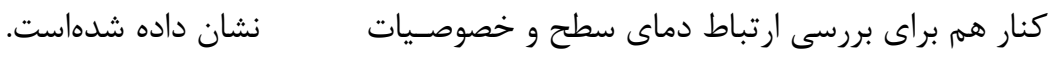

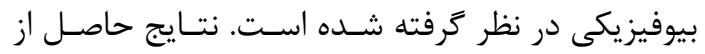


جدول 9: يارامترهاى آمارى ارتباط بين دما و خصوصيات بيوفيزيكى سطح.

\begin{tabular}{|c|c|c|c|c|}
\hline متغير مستقل & ضرايب & انحر اف معيار -خطا & t & prob \\
\hline ثابت & $1,9 \vee 9$ & $\cdot r \mid \wedge \Lambda$ & $\omega_{1} \cdot 10$ & $\cdot \cdots$ \\
\hline روشنايى & - DTFG & $\cdot 1091$ & r,Y人l & $\cdot \cdots 1$ \\
\hline سبزينَى & - etpr &. $.94 \mathrm{~V}$ & $-f, \Delta \wedge \varepsilon$ & $\bullet \cdots$ \\
\hline رطوبت & $-\cdot, \vee \wedge \vee \wedge$ & - TUVG & $-r_{1} \cdot \Delta V$ & $\cdot \cdot r$ \\
\hline R-Squared & •^^ґq & \multicolumn{2}{|c|}{ Mean dependent var } & - tו人 \\
\hline Adjusted R- Squared & - AFVK & \multicolumn{2}{|c|}{ S.D. dependent var } & $\cdot / \Lambda$ \\
\hline S.E. of regression & $\cdot / \cdot \vee \backslash \Lambda$ & \multicolumn{2}{|c|}{ Akaike info criterion } & $-r, T V R$ \\
\hline Sum Squared resid & $\cdot, M F \cdot F$ & \multicolumn{2}{|c|}{ Schwarz criterion } & $-r, f \Delta \Delta$ \\
\hline Log likelihood & $\Lambda V_{1} \cdot V$ & \multicolumn{2}{|c|}{ Hannan-Quinn criter } & 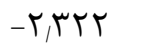 \\
\hline F-Statistic & $\mid r \wedge, \xi \Lambda$ & \multicolumn{2}{|c|}{ Durbin-Watson stat } & $r_{/} / \Delta V$ \\
\hline
\end{tabular}

نتيجه گرفت كه اراضى ساخته شده در همه محـدوده-

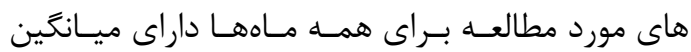
سبزينگى و رطوبت پايينتر و ميانگين روشنايى بالاترى

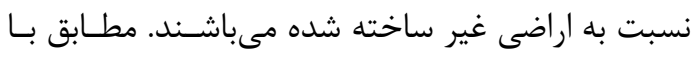

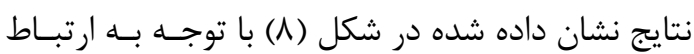
معكوس دماى سطح و خصوصيات سبزينگى و رطوبـت و ارتباط مستقيم دماى سـطح و خصوصـيت روشـنايى

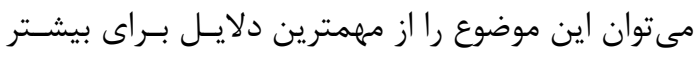

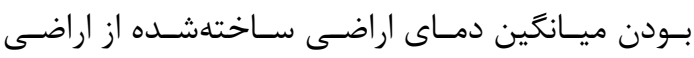

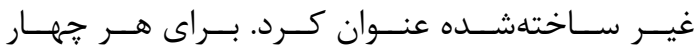
محدوده جغرافيايى مورد مطالعه اختلاف بين ميـانخين


غير ساختهشده در ماههاى فـروردين و تيـر بـهـ نسـبت

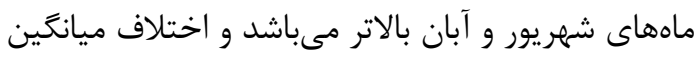

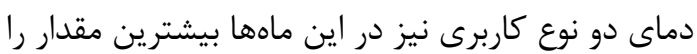
دارد. در محسـدوده قائمشـهر بيشـــرين اخــتلاف مقــادير

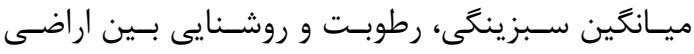

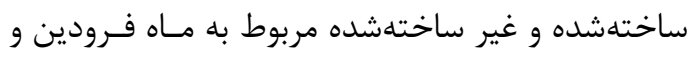

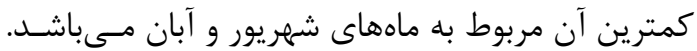

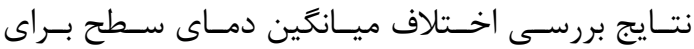
محدوده قائمشهر نيز نشان مى دهد كه بيشترين مقـدار
با توجه به مقـادير حاصـل شـده بــراى آمـاره t و ديخـر

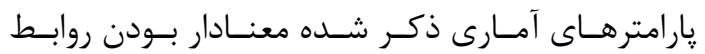

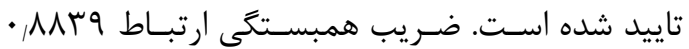

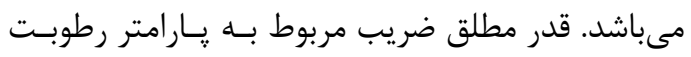
بزركتر از ضرايب سبزينكى و روشنايى سطح مسىباشـد. اين نكته بيانكر اين است كه دماى سـطح بــهـ تغييـرات رطوبت بيشتر از يارامترهاى ديخر واكنش نشـان داده و تغييراتش بيشتر خواهد بود. نتايج بررسى ارتباط بـين دمـاى سـطح و خصوصـيات

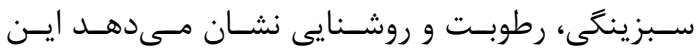

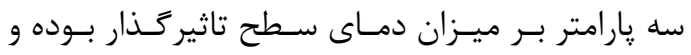

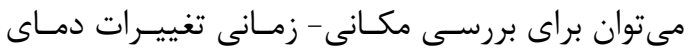
سطح از تحليل اين خصوصيات استفاده كـرد. بنـابراين ين رئن براى محدودههاى مختلف در هر جهار ماه مورد مطالعه،

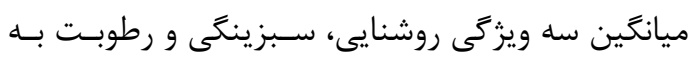
تفكيك اراضى ساختهشده و غير ساخته شـده محاسـبه ويه شده است. نتايج حاصل از محاسبه ميانگين خصوصيات

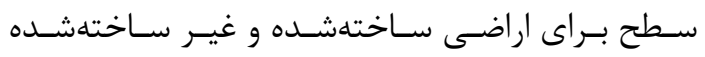
بهصورت جدول (V) نشان داده شده است. از تجزيه و تحليل نتايج نشان داده شده در جـدول

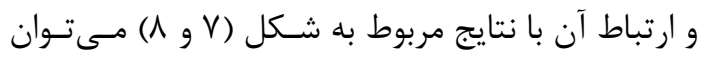


بهشهر نشان مى دهد. بـــاى مـاه آبـان كمتـرين مقـدار

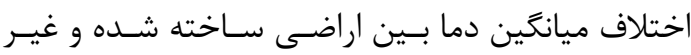
ساختهشده r • مربوط به محدوده نكا مىباشد كمترين

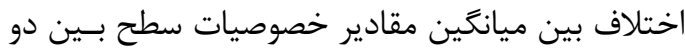

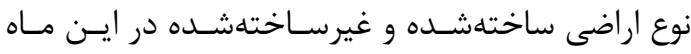
مربوط به محدوده نكا مىباشد.
اختلاف با ه/4 درجه مربوط به ماه فـرودين و كمتـرين

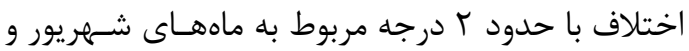

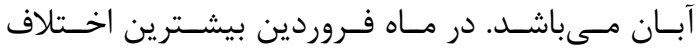

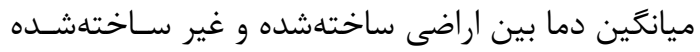

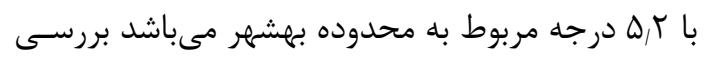
جدول (V) نيز بيشتر ين اختلاف بـين ميـانگين مقـادير

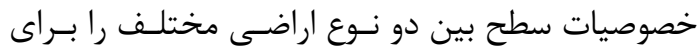

جدول V: ميانگَين خصوصيات سطح براى اراضى ساختهشده و غير ساختهشده.

\begin{tabular}{|c|c|c|c|c|c|c|}
\hline ماه & \multicolumn{2}{|c|}{ خصوصيات سطح و طبقات كاربرى } & قائمشهر & سارى & نكا & بهشهر \\
\hline \multirow{6}{*}{ فروردين } & \multirow{2}{*}{ ر ت بوبت } & اراضى غير ساختهشده & $-90 \cdot$ & -11199 & $-r \cdot r V$ & $-\wedge 91$ \\
\hline & & اراضى ساختهشده & -rita & $-r \wedge \omega \Lambda$ & $-F \cdots$ & 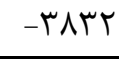 \\
\hline & \multirow{2}{*}{ 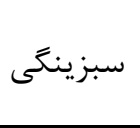 } & اراضى غير ساختهشده & $\Lambda$ & q4V & TFT & $r \cdot v r$ \\
\hline & & اراضى ساختهشده & $-t \cdot r \Lambda$ & -rQTA & $-r \mid G$. & $-r \cdot r q$ \\
\hline & \multirow{2}{*}{ روشنايى } & اراضى غير ساختهشده & FVTV & rV^9r & rANTr & TVTVI \\
\hline & & اراضى ساختهشده & DTRG & r...r & $r \cdot \vee 9 \Delta$ & r৭\&人s \\
\hline \multirow{6}{*}{ تير } & \multirow{2}{*}{ 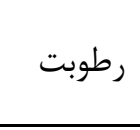 } & اراضى غير ساختهشده & אמזו- & $-r \cdot r \cdot$ & $-r \Delta \Delta \wedge$ & 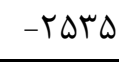 \\
\hline & & اراضى ساختهشده & -FTtK & $-F V \mid \varphi$ & $-F \wedge \vee G$ & $-\Delta \cdot \Delta r$ \\
\hline & \multirow{2}{*}{ سبزينگى } & اراضى غير ساختهشده & roll & TETE & IFFT & $10 \cdot 9$ \\
\hline & & اراضى ساختهشده & -1119 & $-|\wedge \vee|$ & -1991 & $-t \mid Q \Delta$ \\
\hline & \multirow{2}{*}{ 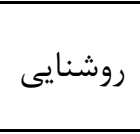 } & اراضى غير ساختهشده & $\uparrow \wedge \Delta \wedge$ & TIDF & TrVTd & rוrqA \\
\hline & & اراضى ساختهشده & $\Delta V_{V I}$ & merq & $r \Delta \cdot \Lambda \Delta$ & TFTVI \\
\hline \multirow{6}{*}{ شهريور } & \multirow{2}{*}{ ر ت رطوبت } & اراضى غير ساختهشده & -MFVR & $-r \& \mid r$ & M & $-r \Delta 9 \Delta$ \\
\hline & & اراضى ساختهشده & $-r q 1 \wedge$ & $-4 \cdot \Lambda 1$ & -FYVT & - frtq \\
\hline & \multirow{2}{*}{ سبزينگى } & اراضى غير ساختهشده & IrF & 119 & $-r \Delta T$ & $V \Delta \Delta$ \\
\hline & & اراضى ساختهشده & שTH & $-r V \cdot 1$ & - r & -YGYA \\
\hline & \multirow{2}{*}{ روشنايى } & اراضى غير ساختهشده & r.r & rq11. & Trtrt & rq991 \\
\hline & & اراضى ساختهشده & $r \cdot \Lambda \Lambda \Lambda$ & TIS. D & rTASV & rr. \\
\hline \multirow{6}{*}{ آبان } & \multirow{2}{*}{ رطوبت } & اراضى غير ساختهشده & $-|r \Delta|$ & -1 HG & -rmat & $-|f \Delta|$ \\
\hline & & اراضى ساختهشده & $-r F \cdot I$ & $-r \Leftrightarrow \Delta 1$ & - -YNFF & $-r \wedge T Y$ \\
\hline & \multirow{2}{*}{ 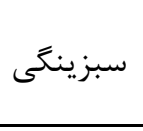 } & اراضى غير ساختهشده & -rMV & $-9 Y$. & $-149 q$ & $-\mathrm{VA \Lambda}$ \\
\hline & & اراضى ساختهشده & -TTHA & $-r 99$. & -rVIr & -TEMd \\
\hline & \multirow{2}{*}{ 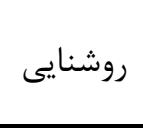 } & اراضى غير ساختهشده & Fr & $r 19 .$. & TMGVT & $r 109$. \\
\hline & & اراضى ساختهشده & q. & $r r \Lambda \cdot r$ & TFF. V & rrVVA \\
\hline
\end{tabular}


براى بررسى توزيع مكـانى جزيـره حرارتى در منطقــه،

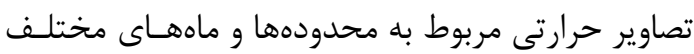

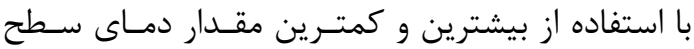
نرمال شد. سيس با استفاده از مقادير ميانكين و انحراف

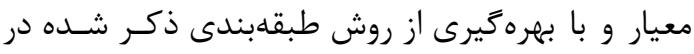

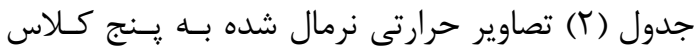
دمايى طبقلبندى شدند. شكل (9) نقشههـاى حرارتى ترى

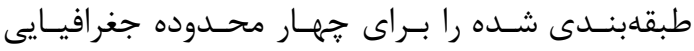

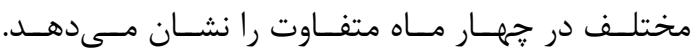

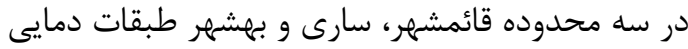

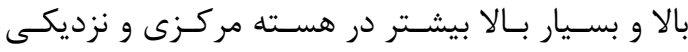
راههاى ارتباطى خروجى از شهر قرار دارند، اطراف شهر نرئ دردي توسط طبقه دمايى متوسط يوشش داده مىشـود ولى رئى مقدار و كيفيت يراكنش طبقات دمـايى طـى مـاهـــاى

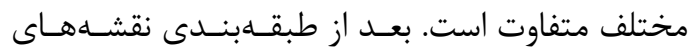
دماى سطح نرمال شـده بــه طبقــات دمـايى، مسـاحت مربوط به هر كاربرى محاسـبه شـده و تغييـرات آن در

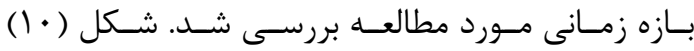

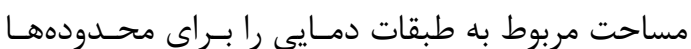
مورد مطالعه در زمانهاى مختلف را نشان مى دهد.
سم-F-F - ارتباط شدت جزيره حرارتى و خصوصـيات بيوفيزيكى

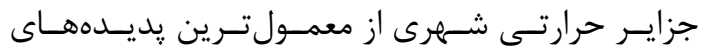

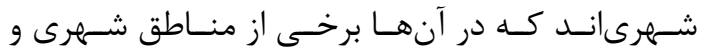

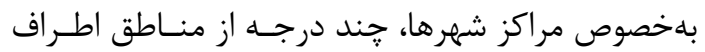

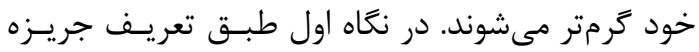
حرارتى شهرى، هر جهار محدوده مورد مطالعه بهدليـل

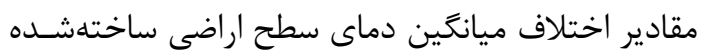

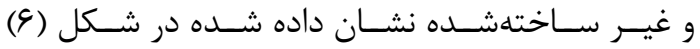
تحت تاثير جزيره حرارتى شهرى قرار دارند. اين موضوع

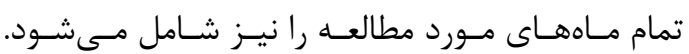
ولى بهدليل تفاوتى كه بين مقادير نشـان داده شـده در شكل (9) براى محدودهها و ماههاى مختلف وجـود دارد مىتوان نتيجه كرفت كه درصد و شدت يديــده جزيــره

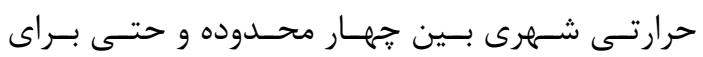

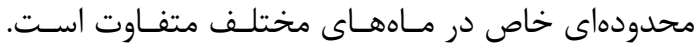

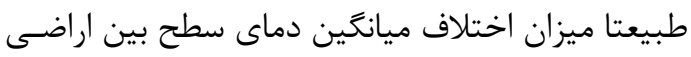

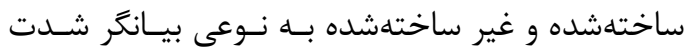
جزيره حرارتى شهرى در منطقه مى باشد. بـا ايـن حـال

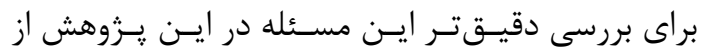
شاخص شدت جزيره حرارتى استفاده شده است. 
بررسى ارتباط بين شدت جزيره حرارتى و ....

محمد كريمى فيروزجايى، مجيد كياورز

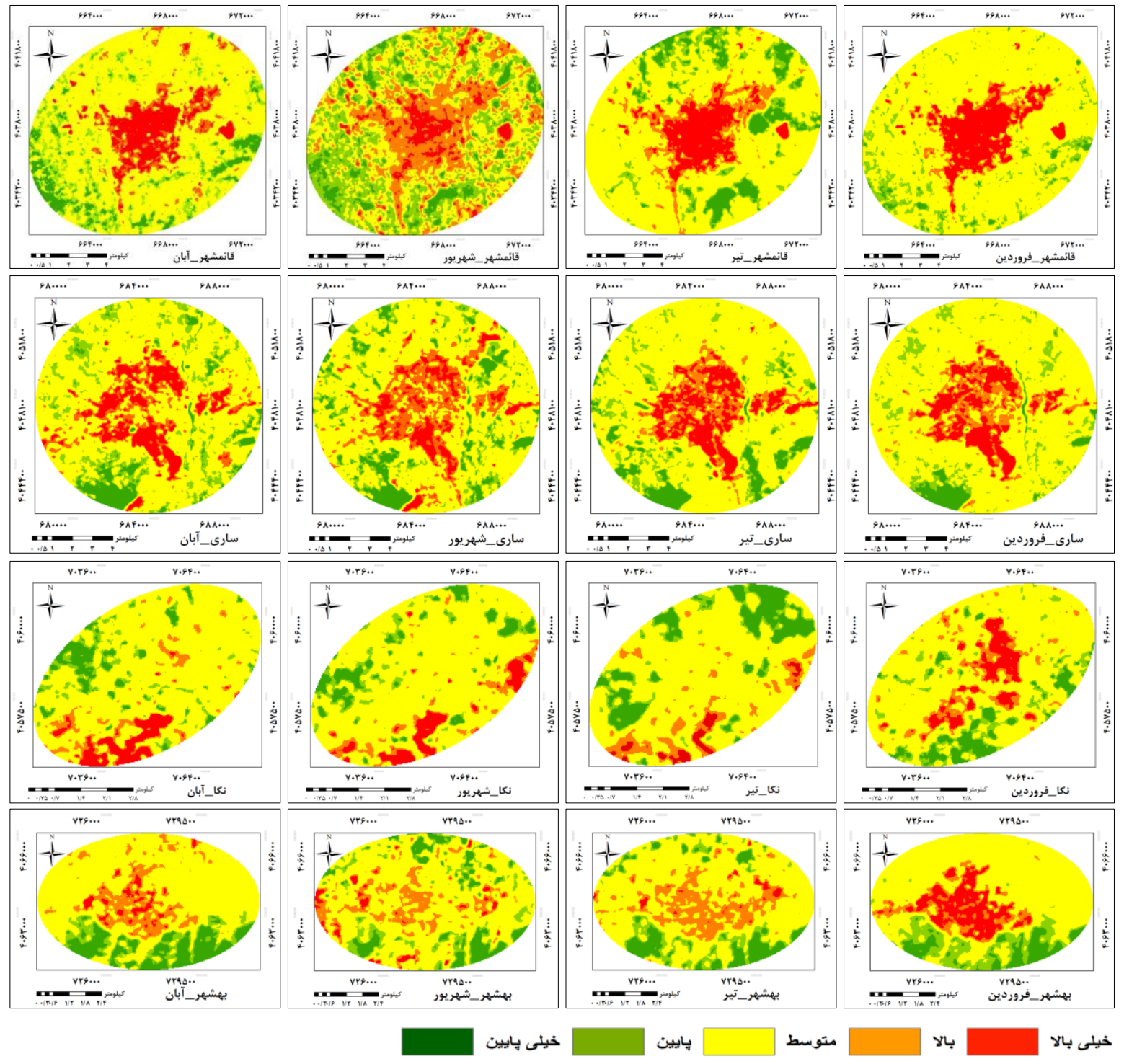

شكل 9: نقشه هاى حرارتى طبقدبندى شده را براى جهار محدوده جغرافيايى مختلف در جهار ماه متفاوت 


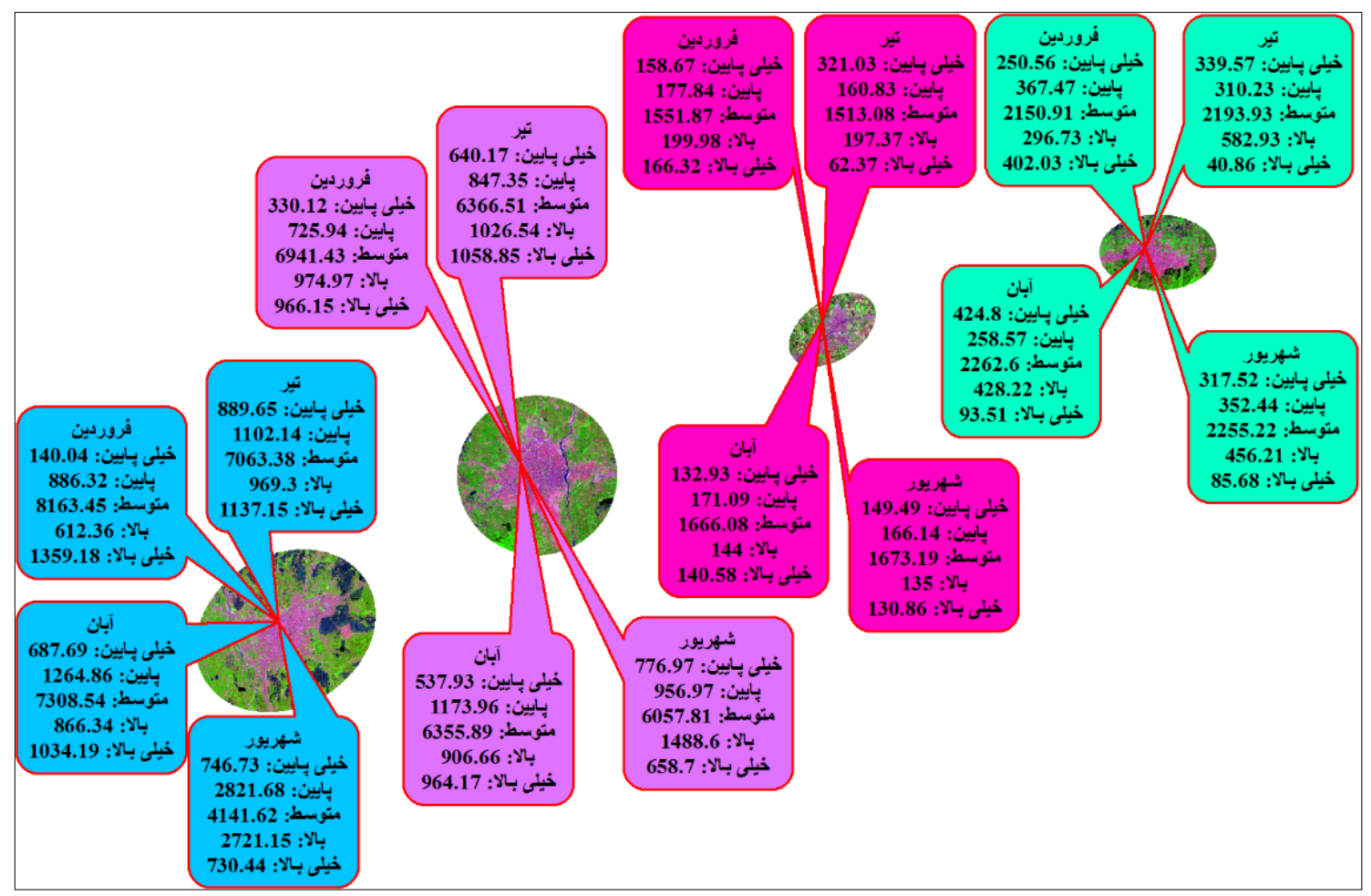

شكل •ا: مساحت مربوط به طبقات دمايى براى محدودههاى جغرافيايى مورد مطالعه در زمانهاى مختلف (هكتار)

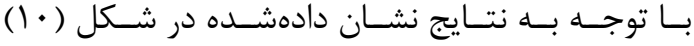

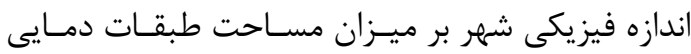
مختلف تـاثير مسـتقيهم دارد. در تمـام مـاههـاى مـورد بررسـى محسـدودههـاى سـارى و قائمشـهر داراى عـدد

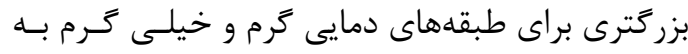

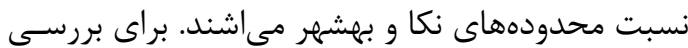
شدت جزيره حرارتى يك محدوده بايد به نــوعى ميـزان

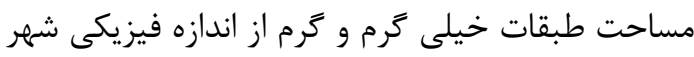

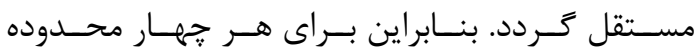
جغرافيايى در جهار ماه متفاوت مساحت طبقات دمـايى مختلف در فضاى اراضى ساخته شـده بررسـى و نتـايج بهصورت جدول (^) نشان داده شده است.
با توجه به نتايج شكل (9 و • () در تمام محسدودههـا و ماههاى مورد مطالعه، طبقه دمـايى متوســ بيشـــرين مساحت رو به خود اختصاص داده است. براى محـدوده مونه قائمشهر در ماه شـهريور بـهـ نسـبت مـاههـاى ديخــر از

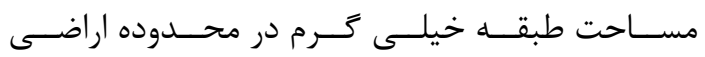
ساختهشده كاسته و به مساحت طبقـه دمـايى گَرم در اين محدوده اضافه شده اسـت. بـه ترتيـب بيشـترين و و كمترين ميزان مساحت طبقه دمايى گرم و خيلى گَرم

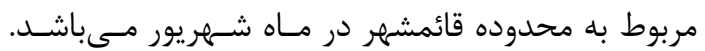
اين درحالى است كه مطابق شـكل (9) در ايـن مـاه در

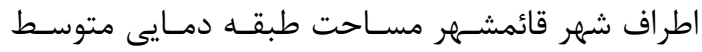
كاهش يافته و به جاى آن خوشههاى جديد مربـوط بـهـ طبقات دمايى پايين و خيلى پايين ايجاد شده است. 
بررسى ارتباط بين شدت جزيره حرارتى و ........

محمد كريمى فيروزجايى، مجيد كياورز بلرئ

جدول ^: مساحت طبقات دمايى مختلف در فضاى اراضى ساخته شده محدودههاى جغرافيايى مختلف در ماههاى مختلف (هكتار (ه)

\begin{tabular}{|c|c|c|c|c|c|}
\hline ماه & طبقات دمايیى & قائمشهر & سارى & نكا & بهشهر \\
\hline \multirow{5}{*}{ فروردين } & خيلى يايين & r, $\wedge \mathrm{V}$ & $1,8 r$ & $1, p F$ & $\cdot .9$ \\
\hline & يايين & IV/AT & $f, 1\}$ & r,VA & $\cdot \pi V$ \\
\hline & متوسط & $11 \vee \wedge, 19$ & $119 \%, 4$ & rrv,VA & $\mid f q, k$ \\
\hline & بالا & $\Delta Y \wedge, \Delta V$ & $\Lambda F V_{1} \cdot V$ & $\mid r r_{1} \cdot r$ & IV. 19 \\
\hline & خيلى بالا & $1 \pi \cdot \cdot 90$ & $q r V / F d$ & 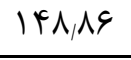 & rqq, \\
\hline \multirow{5}{*}{ تير } & خيلى يايين & $\cdot \Delta F$ & $\cdot, 9$ & $\cdot 11$ & - \\
\hline & يايين & r, & $\uparrow, \varepsilon \wedge$ & $\cdot, 9$ & $\cdot 111$ \\
\hline & متوسط & $111 r, \pi r$ & $11 \cdot r / 0$ & س & 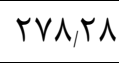 \\
\hline & بالا & $\Delta T 1, \Delta r$ & $\wedge \vee r_{1} / 9$ & $\Delta 1, \cdot r$ & F • r \\
\hline & خيلى بالا & $1 \cdot 91, \Delta r$ & $q 9 q_{/} \cdot \Delta$ & $1, p F$ & $1 \cdot \pi \omega$ \\
\hline \multirow{5}{*}{ شهريور } & خيلى پايين & 9 & $r, \Delta l$ & س & عسر. \\
\hline & يايين & $I V \cdot 1 t q$ & 9,99 & r,va & 1,21 \\
\hline & متوسط & $1 \cdot 9,94$ & $|r| f, q$ & $\Delta \cdot \Delta, r \Delta$ & FIr, EV \\
\hline & بالا & וז人 & $\| T \mid, \Delta \Lambda$ & $r \cdot \wedge \Lambda$ & 198,11 \\
\hline & خيلى بالا & $\Delta \Delta q, \varepsilon r$ & $\Delta T F, T H$ & f, Tr & 9 \\
\hline \multirow{5}{*}{ آبان } & خيلى یايين & $\omega_{1} \cdot \boldsymbol{F}$ & $V_{1} \cdot r$ & $V, F$ &.,$\pi V$ \\
\hline & يايين & 1,90 & 19,79 & $|f| r$, & $\cdot \Delta F$ \\
\hline & متوسط & سK, & $14 \cdot r, q$ & $f \Delta f, \mid F$ & rᄉ \\
\hline & بالا & $\Delta q r, \Delta \Delta$ & $G Q V, f Y$ & $4 q, 0 q$ & | \\
\hline & خيلى بالا & $q \vee T, p q$ & $\wedge \vee \wedge, \Delta \wedge$ & $\Lambda, \Delta \Delta$ & $\varphi \wedge, \wedge \Delta$ \\
\hline
\end{tabular}

9اه ديخر تير، شهريور و آبان خيلى بايين و كمتر از

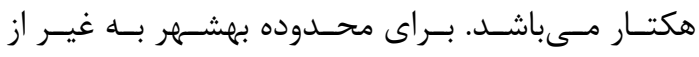

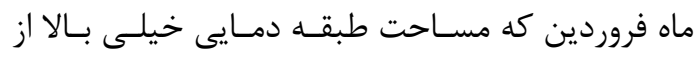

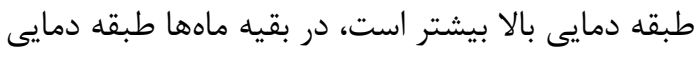

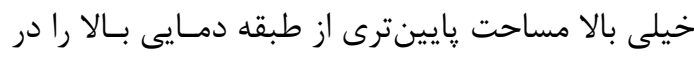

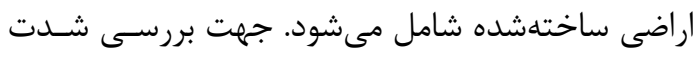

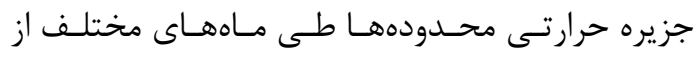

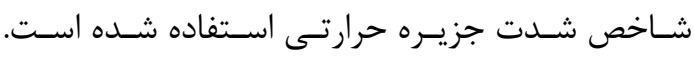

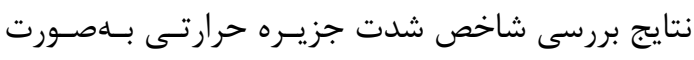
شكل (1) - (1) نشان داده شده است.
طبق جدول (^) مساحت طبقات دمايى بالا و خيلى بالا

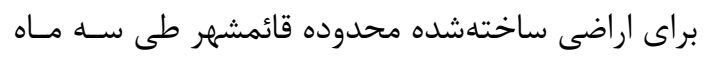

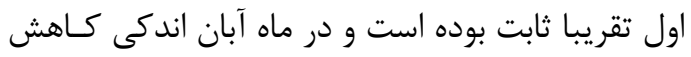

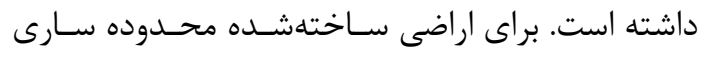
بيشترين مساحت مربوط به طبقات دمائى دارئ بالا و خيلى

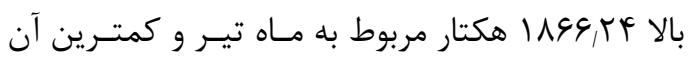

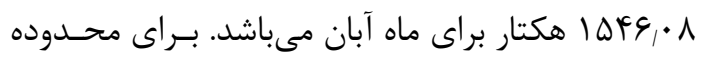

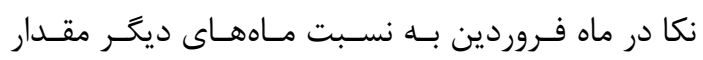

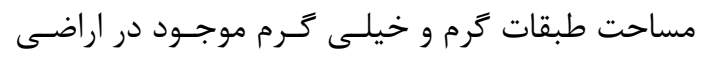

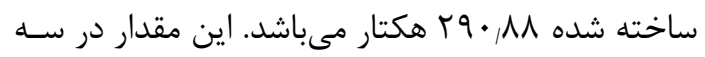




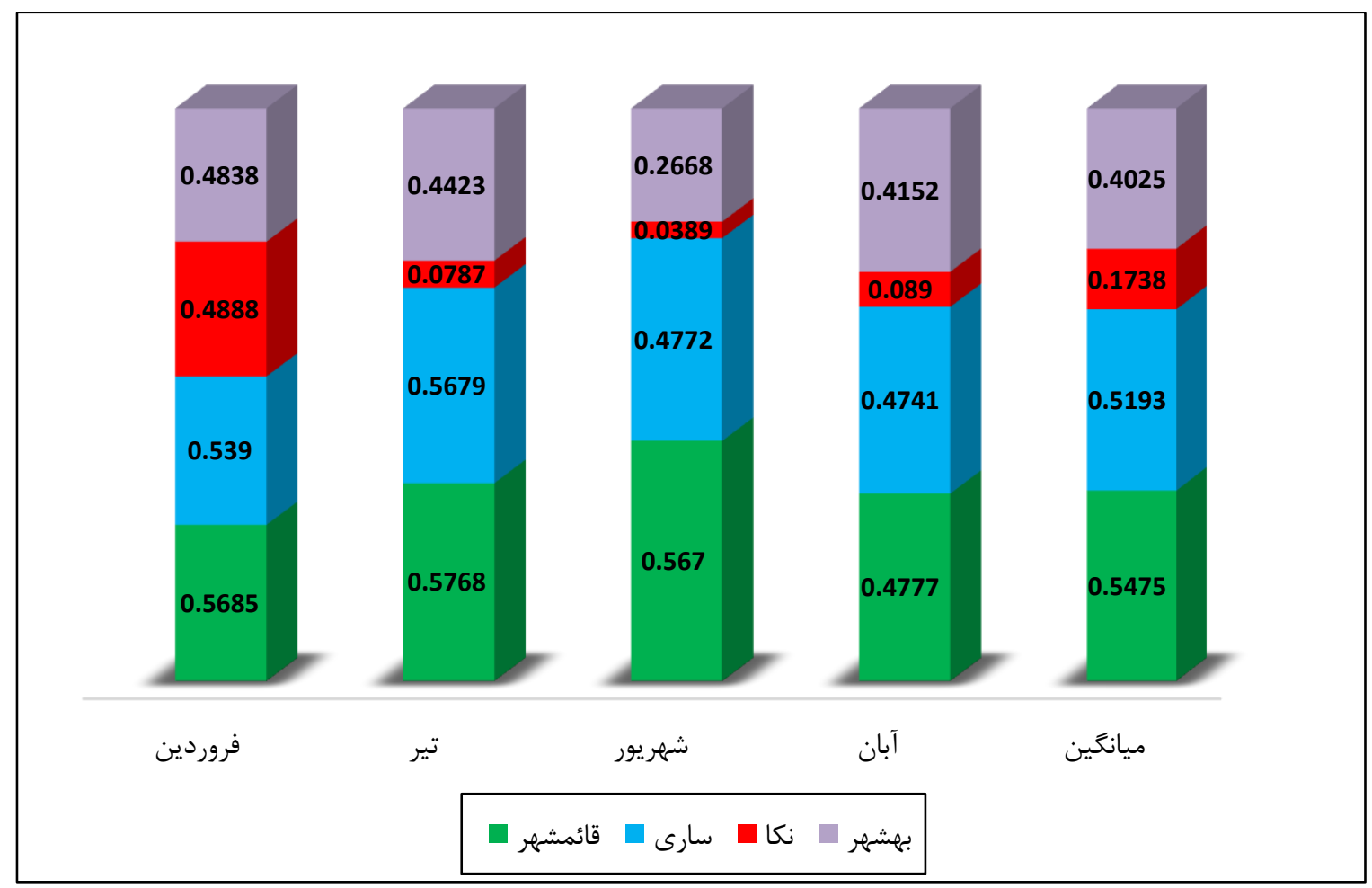

شكل ||: شاخص شدت جزيره حرارتى براى محدودههاى جغرافيايى مختلف در ماههاى متفاوت

در ماههاى مختلف نشان مى دهد كه به ترتيب قائمشهر

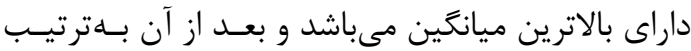

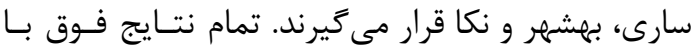

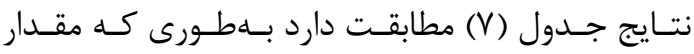

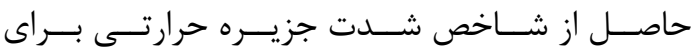

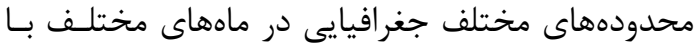

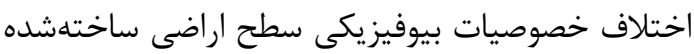
و غير ساختهشده مطابقت و ارتباط مستقيم دارد.

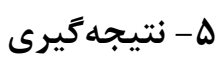

خصوصيات بيوفيزيكى سطح در محدودههاى شـهرهاى شمالى ايران به سـبب قراركيـرى كـاربرى كشـاورزى و

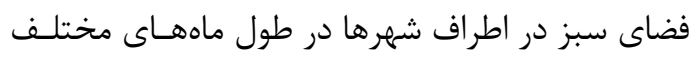

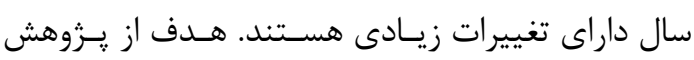

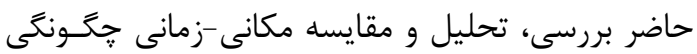

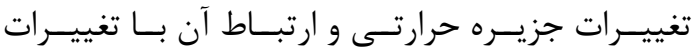

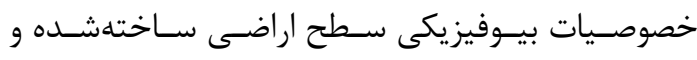
غير ساختهشده شهرهاى واقع در شرق استان مازنـدران

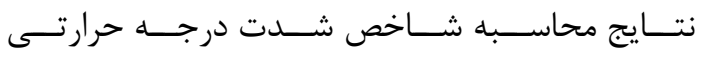

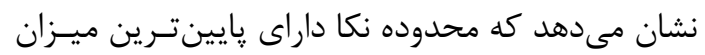
شدت جزيره حرارتى مىباشد. اين محدوده فقط در ماه

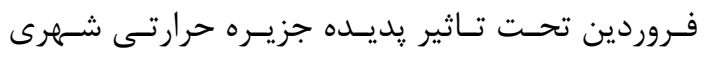

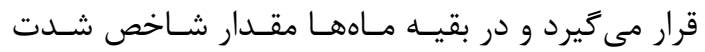
جزيره حرارتى مقدار بسيار يايين را براى ايـن محسدوده نشان مىدهد و حتى به صفر نيز بسيار نزديك مىشود.

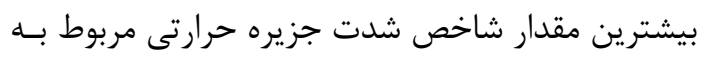

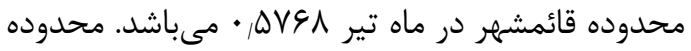
بهشهر نيز در تمام ماهها از شدت جزيره حرارتى نسـبتا بالايى برخوردار اسـت و يـايينتــرين مقـدار آن در مــاه شهريور ب91, • • مىباشد. محدوده جغرافيايى سارى نيز از شدت بالايى يديده جزيره حرارتى شهرى رنج برده و

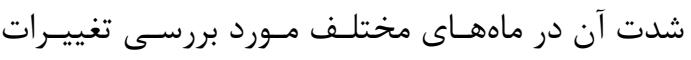

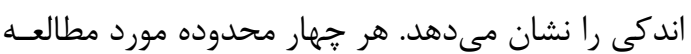
در ماههاى فروردين و تير به نسبت ماههـاى شـهريور و آبان بيشتر تحت تاثير يديده جزيره حرارتى قرار دارنـد. محاسبه ميانگين شدت جزيره حرارتى تهمـار محسدوده 


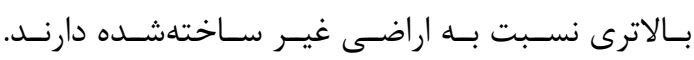

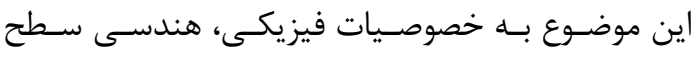

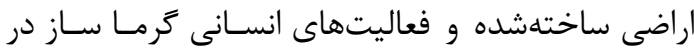

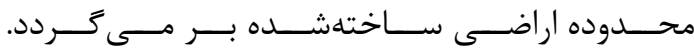

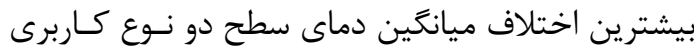

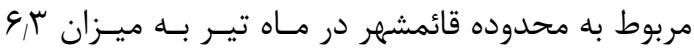
درجه و كمترين آن مربوط به محدوده نكا در ماه آبـان

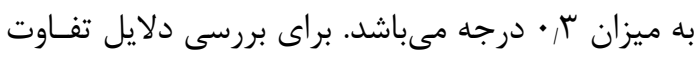

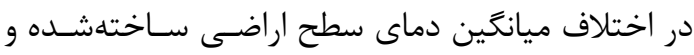

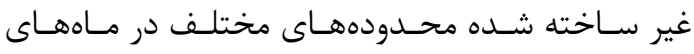

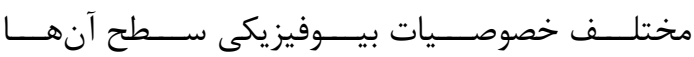
بررسى شده است. نتايج بررسى ارتباط بين دماى سطح

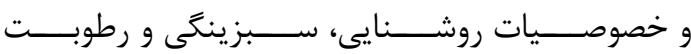

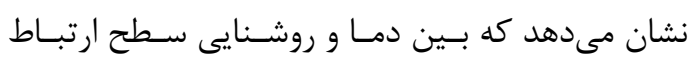

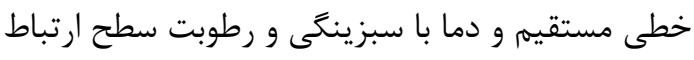

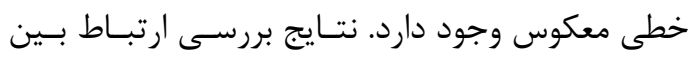
دماى سطح و بيوفيزيكى، ضريب همبستخى بالاى 11 •

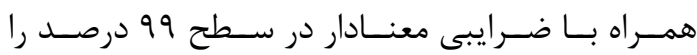
نشان مى دهد. در محدودههاى جغرافيايى و زمـانى كـهـ

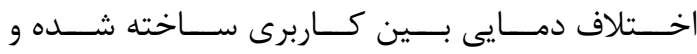

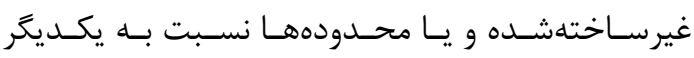

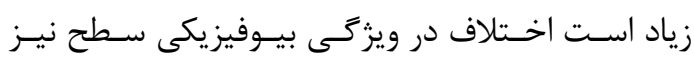

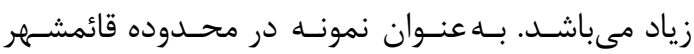
بيشترين اختلاف مقادير ميانكين سـبزينكى، رطوبـت و ونسان

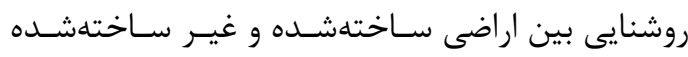

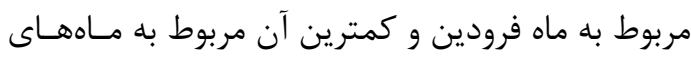
شهريور و آبان مىباشد. نتايج بررسى اختلاف ميـانكين

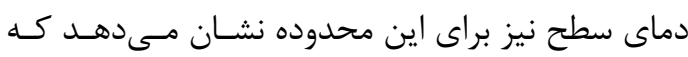

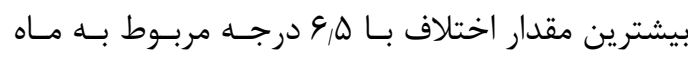

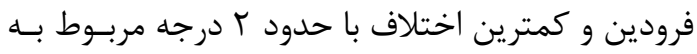

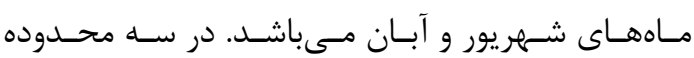

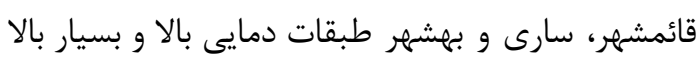

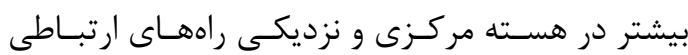

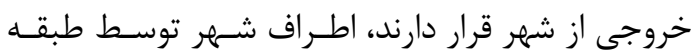

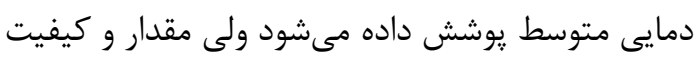

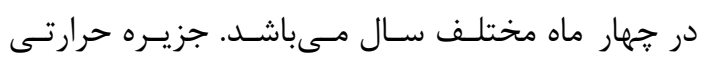

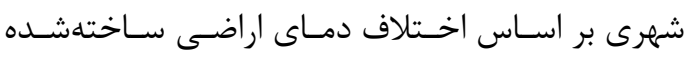

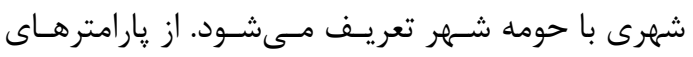

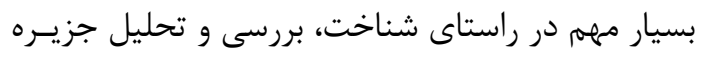

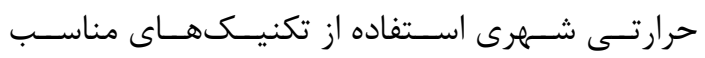

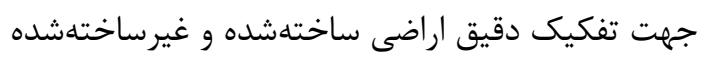
از يكديخر، انتخاب و به كاركيرى روشهاى مناى مناسب براى

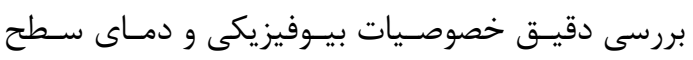

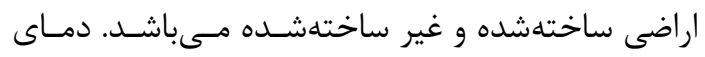
سطح با استفاده از مدل محاسبه دماى سطح تك باندى إنى

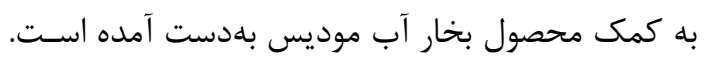

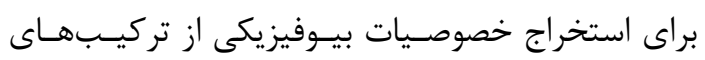

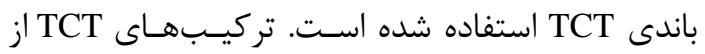



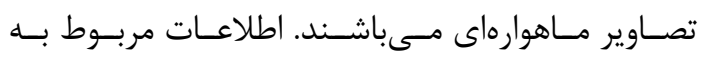

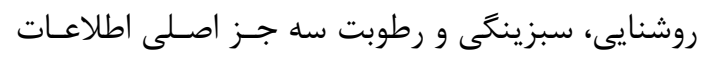
استخراج شده از اين تركيبها مئى رباشند. براى استخراج

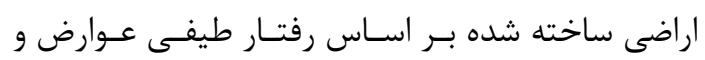

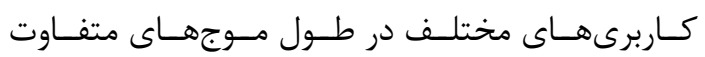

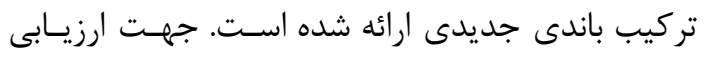

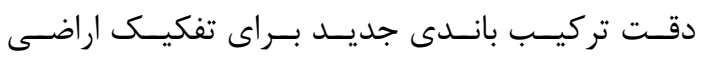

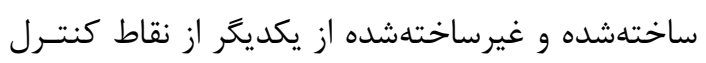

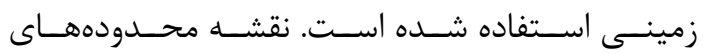

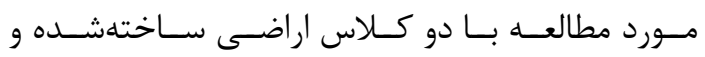

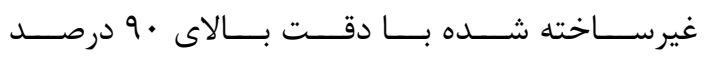

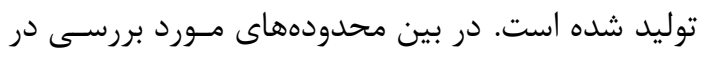

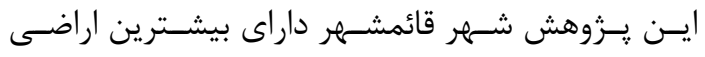

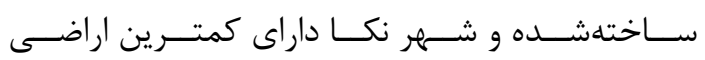
ساخته شده مسىباشـد. در بـين جههار محسـدوده مـورد

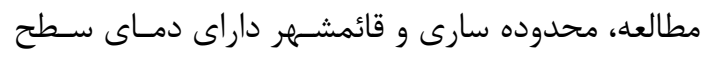

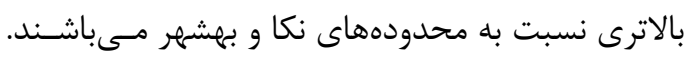

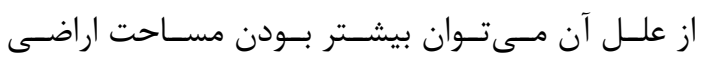
ساخته شده در اين محدودهها بـهـ نسـبت دو محسدوده

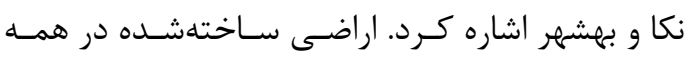

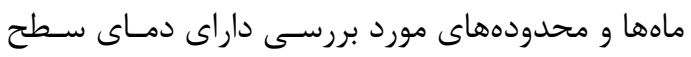




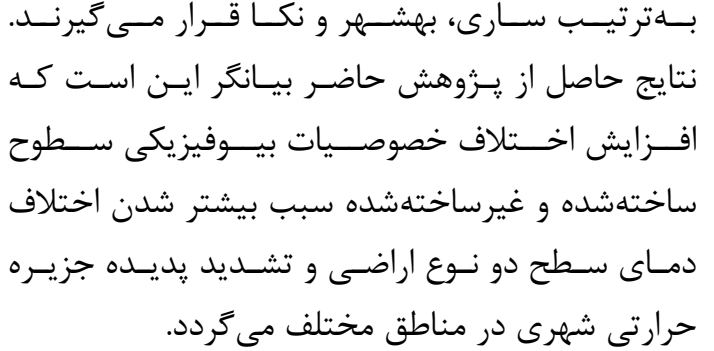

[1] N. Brunsell, "Characterization of landsurface precipitation feedback regimes with remote sensing," Remote Sensing of Environment, vol. 100, no. 2, pp. 200-211, 2006.

[2] N. Schwarz, U. Schlink, U. Franck, and K. Großmann, "Relationship of land surface and air temperatures and its implications for quantifying urban heat island indicatorsAn application for the city of Leipzig (Germany)," Ecological Indicators, vol. 18, pp. 693-704, 2012.

[3] R. Amiri, Q. Weng, A. Alimohammadi, and S. K. Alavipanah, "Spatial-temporal dynamics of land surface temperature in relation to fractional vegetation cover and land use/cover in the Tabriz urban area, Iran," Remote sensing of environment, vol. 113, no. 12, pp. 2606-2617, 2009.

[4] K. P. Gallo and T. W. Owen, "Satellitebased adjustments for the urban heat island temperature bias," Journal of Applied Meteorology, vol. 38, no. 6, pp. 806-813, 1999.

[5] L. Liu and Y. Zhang, "Urban heat island analysis using the Landsat TM data and ASTER data: A case study in Hong Kong," Remote Sensing, vol. 3, no. 7, pp. 15351552, 2011.

[6] M. Santamouris and D. Kolokotsa, "On the impact of urban overheating and extreme climatic conditions on housing, energy, comfort and environmental quality of vulnerable population in Europe," Energy and Buildings, vol. 98, pp. 125-133, 2015.

$$
\begin{aligned}
& \text { يراكنش طبقات دمايى طى مـاههـاى مختلـف متفــاوت }
\end{aligned}
$$

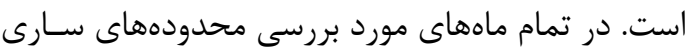

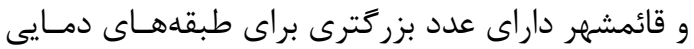

$$
\begin{aligned}
& \text { گرم و خيلى گرم به نسبت محدودههـاى نكـا و بهشـهر } \\
& \text { مىباشند. محاسبه ميانخين شدت جزيره حرارتى جهــار } \\
& \text { محدوده در ماههاى مختلف نشان مي دهد كه بلهترتيسب }
\end{aligned}
$$

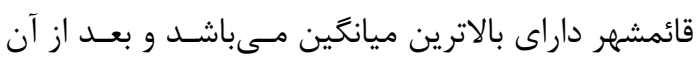

$$
\begin{aligned}
& \text { مراجع }
\end{aligned}
$$

[7] Q. Weng, "Thermal infrared remote sensing for urban climate and environmental studies: Methods, applications, and trends," ISPRS Journal of Photogrammetry and Remote Sensing, vol. 64, no. 4, pp. 335-344, 2009.

[8] C. W. Mackey, X. Lee, and R. B. Smith, "Remotely sensing the cooling effects of city scale efforts to reduce urban heat island," Building and Environment, vol. 49, pp. 348358, 2012.

[9] J. A. Voogt and T. R. Oke, "Thermal remote sensing of urban climates," Remote sensing of environment, vol. 86, no. 3, pp. 370-384, 2003.

[10] K. Gallo, A. McNab, T. Karl, J. Brown, J. Hood, and J. Tarpley, "The use of NOAA AVHRR data for assessment of the urban heat island effect," Journal of Applied Meteorology, vol. 32, no. 5, pp. 899-908, 1993.

[11] J. P. Walawender, M. Szymanowski, M. J. Hajto, and A. Bokwa, "Land surface temperature patterns in the urban agglomeration of Krakow (Poland) derived from Landsat-7/ETM+ data," Pure and Applied Geophysics, vol. 171, no. 6, pp. 913-940, 2014.

[12][12] J. Jiang and G. Tian, "Analysis of the impact of land use/land cover change on land surface temperature with remote sensing," Procedia environmental sciences, vol. 2, pp. 571-575, 2010.

[13] H. Xiao and Q. Weng, "The impact of land use and land cover changes on land surface temperature in a karst area of China," 


\section{بررسى ارتباط بين شدت جزيره حرارتى و ....}

Journal of environmental management, vol. 85, no. 1, pp. 245-257, 2007.

[14] X. Zhang, T. Zhong, X. Feng, and K. Wang, "Estimation of the relationship between vegetation patches and urban land surface temperature with remote sensing," International Journal of Remote Sensing, vol. 30, no. 8, pp. 2105-2118, 2009.

[15] S. Haashemi, Q. Weng, A. Darvishi, and S. K. Alavipanah, "Seasonal variations of the surface urban heat island in a semi-arid city," Remote Sensing, vol. 8, no. 4, p. 352, 2016.

[16]F. Yuan and M. E. Bauer, "Comparison of impervious surface area and normalized difference vegetation index as indicators of surface urban heat island effects in Landsat imagery," Remote Sensing of environment, vol. 106, no. 3, pp. 375-386, 2007.

[17] M. H. A. Baig, L. Zhang, T. Shuai, and Q. Tong, "Derivation of a tasselled cap transformation based on Landsat 8 atsatellite reflectance," Remote Sensing Letters, vol. 5, no. 5, pp. 423-431, 2014.

[18] Q. Liu, G. Liu, C. Huang, and C. Xie, "Comparison of tasselled cap transformations based on the selective bands of Landsat 8 OLI TOA reflectance images," International Journal of Remote Sensing, vol. 36, no. 2, pp. 417-441, 2015.

[19] Q. Liu, G. Liu, C. Huang, S. Liu, and J. Zhao, "A tasseled cap transformation for Landsat 8 OLI TOA reflectance images," in Geoscience and Remote Sensing Symposium (IGARSS), 2014 IEEE International, 2014, pp. 541-544: IEEE.
[20]H. Xu, "A new index for delineating built up land features in satellite imagery," International Journal of Remote Sensing, vol. 29, no. 14, pp. 4269-4276, 2008.

[21] M. Waqar, J. Mirza, R. Mumtaz, and E. Hussain, "Development of new indices for extraction of built-up area \& bare soil from landsat data," Open Access Scientific Reports, vol. 1, no. 1, pp. 01-04, 2012.

[22] A. R. As-Syakur, I. Adnyana, I. W. Arthana, and I. W. Nuarsa, "Enhanced built-up and bareness index (EBBI) for mapping built-up and bare land in an urban area," Remote Sensing, vol. 4, no. 10, pp. 2957-2970, 2012.

[23] J. C. Jimenez-Munoz, J. A. Sobrino, D. Skokovic, C. Mattar, and J. Cristobal, "Land Surface Temperature Retrieval Methods From Landsat-8 Thermal Infrared Sensor Data," (in English), Ieee Geoscience and Remote Sensing Letters, vol. 11, no. 10, pp. 1840-1843, Oct 2014.

[24] J. C. Jiménez - Muñoz and J. A. Sobrino, "A generalized single - channel method for retrieving land surface temperature from remote sensing data," Journal of Geophysical Research: Atmospheres, vol. 108, no. D22, 2003.

[25]H. Xu, Y. Chen, S. Dan, and W. Qiu, "Spatial and temporal analysis of urban heat Island effects in Chengdu City by remote sensing," in Geoinformatics, 2011 19th International Conference on, 2011, pp. 1-5: IEEE. 


\title{
Investigating the relationship between heat island intensity and biophysical characteristics differences between built-up and non- built-up regions (Case Study: Cities in East Mazandaran)
}

Mohammad Karimi Firozjaei ${ }^{1}$, Majid Kiavarz ${ }^{2^{*}}$

1- PhD Student, Department of Remote Sensing and GIS, University of Tehran

2- Asistant Professor, Department of Remote Sensing and GIS, University of Tehran

\begin{abstract}
Biophysical characteristics and surface temperature are the key parameters to monitor and evaluate the physical and chemical processes of the earth's surface. The aim of this study is to investigate the relationship between urban heat island intensity and different biophysical characteristics in built-up and non-built-up lands. For this purpose, the four Landsat 8 satellite images and MODIS water vapor product in dates of April 10th 2016, June 29th 2016, August 27th 2014 and October 29th 2016 for cities of Ghaemshahr, Sari, Neka and Behshahr have been used. Single-channel algorithm was used to calculate the land surface temperature. A band combination tasseled cap extraction was used to estimate some surface biophysical characteristics as well. Also, a new method has been used to extract built-up regions. Finally, LST and biophysical characteristics for built-up and non-built-up regions were analyzed and then, correlations between them and heat island intensity have been surveyed in four months. The result showed that correlation coefficient of relationships between LST and biophysical characteristics surface was 0/88. Increase of differences between biophysical properties in built-up and non-built-up regions causes increase of the temperature difference between the two types of regions and so, intensification of urban heat island. For this reason, temperature difference between built-up and non-built-up regions varied between 0.3-6.4 K $\square$. The highest and lowest heat island intensity corresponding to Ghaemshahr and Neka were estimated 0.5768 and 0.03 respectively.
\end{abstract}

Key words: Heat island intensity, Biophysical characteristics, Built-up land, Non built-up land.

Correspondence Address. Tehran, Enghelab Square, Vesal Shirazi Street, Geography Faculty of Tehran Univercity

Tel: +989123301922

Email : Kiavarzmajid@ut.ac.ir 